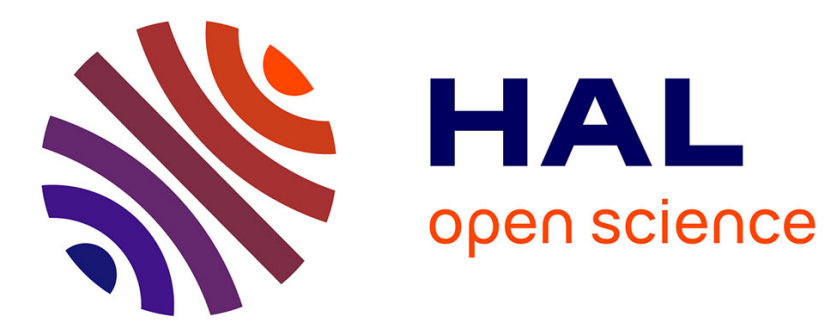

\title{
Impact of climate and land cover changes on snow cover in a small Pyrenean catchment
}

Camille Szczypta, Simon Gascoin, Thomas Houet, Olivier Hagolle, Jean-François Dejoux, C Vigneau, Pascal Fanise

\section{- To cite this version:}

Camille Szczypta, Simon Gascoin, Thomas Houet, Olivier Hagolle, Jean-François Dejoux, et al.. Impact of climate and land cover changes on snow cover in a small Pyrenean catchment. Journal of Hydrology, 2015, 521, pp.84-99. 10.1016/j.jhydrol.2014.11.060 . hal-01194488

\section{HAL Id: hal-01194488 \\ https://hal-univ-tlse2.archives-ouvertes.fr/hal-01194488}

Submitted on 7 Sep 2015

HAL is a multi-disciplinary open access archive for the deposit and dissemination of scientific research documents, whether they are published or not. The documents may come from teaching and research institutions in France or abroad, or from public or private research centers.
L'archive ouverte pluridisciplinaire HAL, est destinée au dépôt et à la diffusion de documents scientifiques de niveau recherche, publiés ou non, émanant des établissements d'enseignement et de recherche français ou étrangers, des laboratoires publics ou privés. 


\title{
Impact of climate and land cover changes on snow cover in a small Pyrenean catchment
}

\author{
C. Szczypta ${ }^{\mathrm{a}, *}$, S. Gascoin ${ }^{\text {a }}$, T. Houet ${ }^{\mathrm{b}}$, O. Hagolle ${ }^{\mathrm{a}}$, J.-F. Dejoux ${ }^{\mathrm{a}}$, C. Vigneau ${ }^{\mathrm{b}}$, P. Fanise ${ }^{\mathrm{a}}$ \\ ${ }^{a}$ Centre d'Etudes Spatiales de la Biosphère (CESBIO), Toulouse, France \\ ${ }^{\mathrm{b}}$ Géographie de l'Environnement (GEODE), Toulouse, France
}

\section{A R T I C L E I N F O}

\section{Article history:}

Received 1 February 2014

Received in revised form 12 November 2014

Accepted 22 November 2014

Available online 5 December 2014

This manuscript was handled by

Konstantine P. Georgakakos, Editor-in-Chief,

with the assistance of Daqing Yang,

Associate Editor

\section{Keywords:}

Snow cover

Climate change

Land cover change

Pyrenees

\begin{abstract}
S U M M A R Y
The seasonal snow in the Pyrenees Mountains is an essential source of runoff for hydropower production and crop irrigation in Spain and France. The Pyrenees are expected to undergo strong environmental perturbations over the 21st century because of climate change (rising temperatures) and the abandonment of agro-pastoral areas (reforestation). Both changes are happening at similar timescales and are expected to have an impact on snow cover. The effect of climate change on snow in the Pyrenees is well understood, but the effect of land cover changes is much less documented. Here, we analyze the response of snow cover to a combination of climate and land cover change scenarios in a small Pyrenean catchment (Bassiès, $14.5 \mathrm{~km}^{2}$, elevation range 940-2651 m a.s.l.) using a distributed snowpack evolution model. Climate scenarios were constructed from the output of regional climate model projections, whereas land cover scenarios were generated based on past observed changes and an inductive pattern-based model. The model was validated over a snow season using in situ snow depth measurements and high-resolution snow cover maps derived from SPOT (Satellite Pour l'Observation de la Terre - Earth Observation Satellite) satellite images. Model projections indicate that both climate and land cover changes reduce the mean snow depth. However, the impact on the snow cover duration is moderated in reforested areas by the shading effect of trees on the snow surface radiation balance. Most of the significant changes are expected to occur in the transition zone between $1500 \mathrm{~m}$ a.s.l. and $2000 \mathrm{~m}$ a.s.l. where (i) the projected increase in air temperatures decreases the snow fraction of the precipitation and (ii) the land cover changes are concentrated. However, the consequences on the runoff are limited because most of the meltwater originates from high-elevation areas of the catchment, which are less affected by climate change and reforestation.
\end{abstract}

(c) 2014 Elsevier B.V. All rights reserved.

\section{Introduction}

The Pyrenees mountain range is located in southwest Europe between France and Spain (mean latitude $42.4^{\circ} \mathrm{N}$ ) and represents a water tower for the regions of northern Spain and southwest France in which the runoff from the Pyrenean watersheds is used for hydropower production, crop irrigation, urban consumption and power plant supplies. Most of the wintertime precipitation in the Pyrenees falls as snow; therefore, snowmelt is a major contributor to the river discharge in spring and summer when water needs for crop irrigation are the highest (López-Moreno and García-Ruiz, 2004).

The Intergovernmental Panel on Climate Change (IPCC) emphasized that climate change will likely have a more acute effect on

\footnotetext{
* Corresponding author.

E-mail address: camille.szczypta@gmail.com (C. Szczypta).
}

the mountainous areas located in southern Europe such as the Pyrenees because of increases of the mean temperatures (Pachauri, 2008; IPCC report, 2013). In addition, a relatively fast and widespread increase in forest cover in the Pyrenees is occurring as a result of the abandonment of rural activities (Vicente-Serrano et al., 2004; Poyatos et al., 2003; Galop et al., 2011).

Both climate and land cover changes are expected to modify the water availability in the lowland areas where the pressure on water resources is already strong (García-Ruiz and Lana-Renault, 2011; López-Moreno et al., 2011; López-Moreno et al., 2014).

Climate model projections have indicated that future climatic conditions are likely to have a substantial impact on the water resource availability in the main Pyrenean basins. Several studies reported an increase in mean annual air temperature of approximately $+3{ }^{\circ} \mathrm{C}$ by the end of the 21st century in the Pyrenees region, which translates to a decrease in streamflow during the irrigation 
period because of earlier seasonal snowmelting (Beniston, 2003a; Beniston et al., 2003b; López-Moreno et al., 2008; Majone et al., 2012). The changes in precipitation are more contrasted depending on the season, but a slight decrease in the mean annual value is expected (Majone et al., 2012).

In addition, the ongoing land cover changes have and will continue to have a profound impact on the dominant hydrological processes in the Pyrenees (Gallart and Llorens, 2004; Morán-Tejeda et al., 2010; López-Moreno et al., 2011). Even if some studies conducted in this region (see e.g., López-Moreno et al., 2011; Graveline et al., 2014) showed that in the Ebro catchment, water yield is mainly affected by water consumption and diversions for agricultural activities, Gallart and Llorens (2004) and López-Moreno et al. (2011) attributed a decrease in water yield of the Ebro River to an increase in forest cover in the catchment area. Indeed, many headwater Pyrenean catchments are not yet affected by artificial uptakes. However, possible land cover change impacts on the water resources in the Pyrenees are multiple and thus difficult to isolate at a regional scale (Morán-Tejeda et al., 2010; LópezMoreno et al., 2014). In a temperate mountainous region such as the Pyrenees, the possible impacts of land cover changes include changes in evapotranspiration, runoff generation processes and snow melt (e.g., Andréassian, 2004). In the Pyrenees, it has been shown that increasing forest areas led to an increase in evapotranspiration (Gallart and Llorens, 2004; López-Moreno et al., 2011) and to reduce storm runoff intensity during moderate events (Gallart and Llorens, 2004; López-Moreno et al., 2008). Using a hydrological model, Delgado et al. (2010) simulated a decrease in runoff under a reforestation scenario in a small rainfall-Pyrenean headwater catchment. However, to our knowledge, the effect of changes in land cover on the snow cover has not been addressed in the Pyrenees.

Land cover is known to control the snow processes in mountainous areas (see Varhola et al., 2010 for a thorough review of the empirical evidence in the literature). Many studies have investigated the effect of vegetation type on snow accumulation and melting processes (Hedstrom and Pomeroy, 1998; Koivusalo and Kokkonen, 2002; Pomeroy et al., 2002; Lundberg et al., 2004; Mellander et al., 2005; López-Moreno and Latron, 2008). The SnowMIP-2 project (Essery et al., 2009) evaluated the ability of snowpack models to represent forest snow processes. A model comparison was performed to understand the interactions between forest and snow in meteorological, hydrological and ecological modeling. Indeed, when an area is covered by low vegetation, such as grassland or subalpine meadows, snow falls directly on the ground. Conversely, in an area covered by high or intermediate vegetation, such as deciduous or conifer forests, the tree branches intercept a significant amount of snow before it reaches the ground (Andréassian, 2004). The intercepted snow is immediately submitted to sublimation processes and returns to the atmosphere; therefore, forests tend to increase snow interception and decrease snow deposition and accumulation on the ground. This physical process has been shown in numerous studies, and the conclusion is that snow accumulation is lower under the forest canopy than in clearcuts, whereas snow melt rates are slower under forests (Jost et al., 2007; López-Moreno and Latron, 2008; Varhola et al., 2010). If the snow deposition on the ground is reduced, the amount of snow available to the soil is smaller and the snow albedo tends to drop rapidly; the snow albedo is also affected by the "litter effect," which reduces the under-canopy snow albedo because of the deposition of organic materials from the trees (Hardy et al., 2000). By decreasing the snow albedo, high vegetation tends to accelerate the snowmelt. Conversely, a high vegetation canopy tends to shield the snowpack from incoming solar radiation, resulting in lower melting rates than snowpack associated with low vegetation or bare soil (Marks et al., 1998; Talbot et al., 2006). All of these vegetation effects are contradictory during the melting phase, and in a specific area, it is important to understand the processes that produce the greatest snowmelt and if the snow melts faster or slower with higher land cover. The processes by which vegetation influences the snowpack are generally dependent upon the climatic conditions (López-Moreno and Latron, 2008; Essery et al., 2009). Therefore, both climate and land use changes should be considered in a combined framework to estimate the response of the snow cover to future conditions in the Pyrenees.

In the framework of the Pyrenees Climate Change Observatory (OPCC, http://www.opcc-ctp.org), the objective of this study is to gain insights into the likely effects of climate and land-use changes on snow cover in the Pyrenees. The impact of climate change alone on snow and hydrology in the Pyrenees was already investigated in previous studies (Beniston, 2003a; Beniston et al., 2003b; LópezMoreno et al., 2008; Majone et al., 2012) and is currently being addressed in the SCAMPEI project (French acronym for climate scenarios designed for mountain areas: extreme phenomena snow cover and uncertainties, Déqué, 2010) by using ad hoc dynamical and/or statistical downscaling of General Circulation Model (GCM) outputs. Here, we aim at characterizing the sensitivity of the snow cover to a likely combination of climate and land cover changes at the end of 21 st century at the scale of a small headwater catchment in the Pyrenees. The study area is the Bassiès catchment $\left(14.5 \mathrm{~km}^{2}\right)$, which is located in the Ariège French department (northeastern Pyrenees). This site was chosen because it is a well-studied and representative area of a common scenario in the Pyrenean massif: after thousands of years of intense agro-silvo-pastoral activities (Galop and Jalut, 1994), the region experienced a rapid rural depopulation during the first half of the 20th century that generated a rapid reforestation at all altitudes (Houet et al., 2012). Since 2009, a Human-Environment Observatory (http://w3.ohmpyr.univ-tlse2.fr/presentation_ohm_pyr.php) was set up in this region by the Institute of Ecology and Environment of the French National Center for Scientific Research (InEECNRS) to study the interactions between ecological, hydrological and human society phenomena. For this study, an automatic weather station was installed in the Bassiès area to monitor surface-level meteorological conditions and snow depth. The meteorological forcing observed at the Bassiès station on an hourly basis and the current vegetation map are used to run and validate a snowpack model over the 2011-2012 snow season. We selected SnowModel (Liston and Elder, 2006a), a physically based distributed snowpack evolution model, because it provides a comprehensive framework for snow cover modeling in complex terrain, and can model the spatial interpolation of meteorological input data and simulate physiographic effects on the snowpack, including the typical parameterizations for vegetation effects on snow processes. In addition, it allows a description of the snow cover in two dimensions, which enables a comparison with remote sensing data.

After a description of the study site, data, methods and SnowModel, we investigate the model's ability to simulate snow depth using in situ observations (plot-scale validation) and remotely sensed data (catchment-scale validation). Model projections of snow depth are then produced and analyzed using different temperatures, precipitation amounts and land cover scenarios, first independently and secondly, all combined, to assess the impact of climate and land use changes on the snowpack over the study site. Lastly, expected temperature and vegetation changes are investigated to understand how they impact the different components of the snowpack mass balance and in particular, the meltwater runoff at the basin catchment downstream. 


\section{Data and methods}

\subsection{Study site}

The study catchment is located in the Ariège Pyrenees, France, and is one of the main sub-basins of the Upper Vicdessos Valley (see Fig. 1). Elevation ranges between 940 and $2651 \mathrm{~m}$ a.s.l. (median elevation $1930 \mathrm{~m}$ ), with a contrasted relief: Figs. 1 and 2a show that at the down part, slopes are gentle and the vegetation cover is principally forest formed by conifer and deciduous trees; at the intermediate part of the basin, the area is flat and covered by grassland rangeland and subalpine meadow; and above this valley, slopes are steeper and there is less vegetation and more bare soil. The catchment is ungauged, but the streamflow at the outlet is diverted toward a hydropower plant operated by Electricité de France. There are two small reservoir lakes in the lowest area of the Bassiès catchment (Etang Majeur and Etang d'Escalès) but there is no diversion or pumping from these lakes for irrigation, only a water inlet in the Etang d'Escalès, which feeds the Bassiès hydropower plant through a penstock. The average annual temperature in the area is $6.6^{\circ} \mathrm{C}$ and precipitation is $1640 \mathrm{~mm}$, of which $30 \%$ falls as snow, which is according to the SAFRAN $8 \mathrm{~km}$ resolution gridded dataset over the 2000-2012 period (Quintana-Seguí et al., 2008). The snow season generally starts in NovemberDecember and ends in April-May depending on the year. In terms of vegetation, the catchment is covered by $2 \%$ forest, $67 \%$ subalpine meadow, $5 \%$ intermediate vegetation (scattered short-conifer), and $23 \%$ rock and bare soil; lakes represent $3 \%$ of the surface basin catchment. Fig. 2a shows the current land cover map, which was produced by combining an object-based approach and visual interpretation of aerial photographs. The object-based approach attempts to segment landscape units that appear homogeneous in terms of texture, structure and spectral value (average size of units equals several hundred square meters). Visual interpretation integrates knowledge and historical observations (historical aerial photographs, past land cover maps) to classify the dominant land cover types (described in Fig. 2; Houet et al., 2012; Houet et al. 2014).

\subsection{Meteorological data}

Long meteorological records are generally not available in small mountainous catchments, and the variability of the climate is very high in mountains. In order to get a short but accurate and selfcontained meteorological record to run and validate SnowModel, a meteorological station was installed in the study catchment (Lat: $42^{\circ} 45.9^{\prime} \mathrm{N}$; Lon: $1^{\circ} 24.9^{\prime} \mathrm{E}$, elevation $1650 \mathrm{~m}$ a.s.l.). This allowed us to measure all the meteorological variables needed to close the snowpack energy budget, i.e. including incoming longwave and shortwave radiations. These variables are not measured by standard weather stations operated by the meteorological agencies in the Pyrenees, which restrict the applicability of statistical downscaling for snow studies.

This automatic weather station was equipped with researchgrade meteorological sensors, a Campbell CR1000 datalogger powered by a solar panel (Table 1 ). The acquisition frequency was set to $0.1 \mathrm{~Hz}$. The datalogger recorded the half-hourly averages of air temperature, air humidity, incoming longwave and shortwave radiation, wind speed, wind direction and snow depth. The station was set up on Nov. 10, 2011 in an open and flat area in the center of

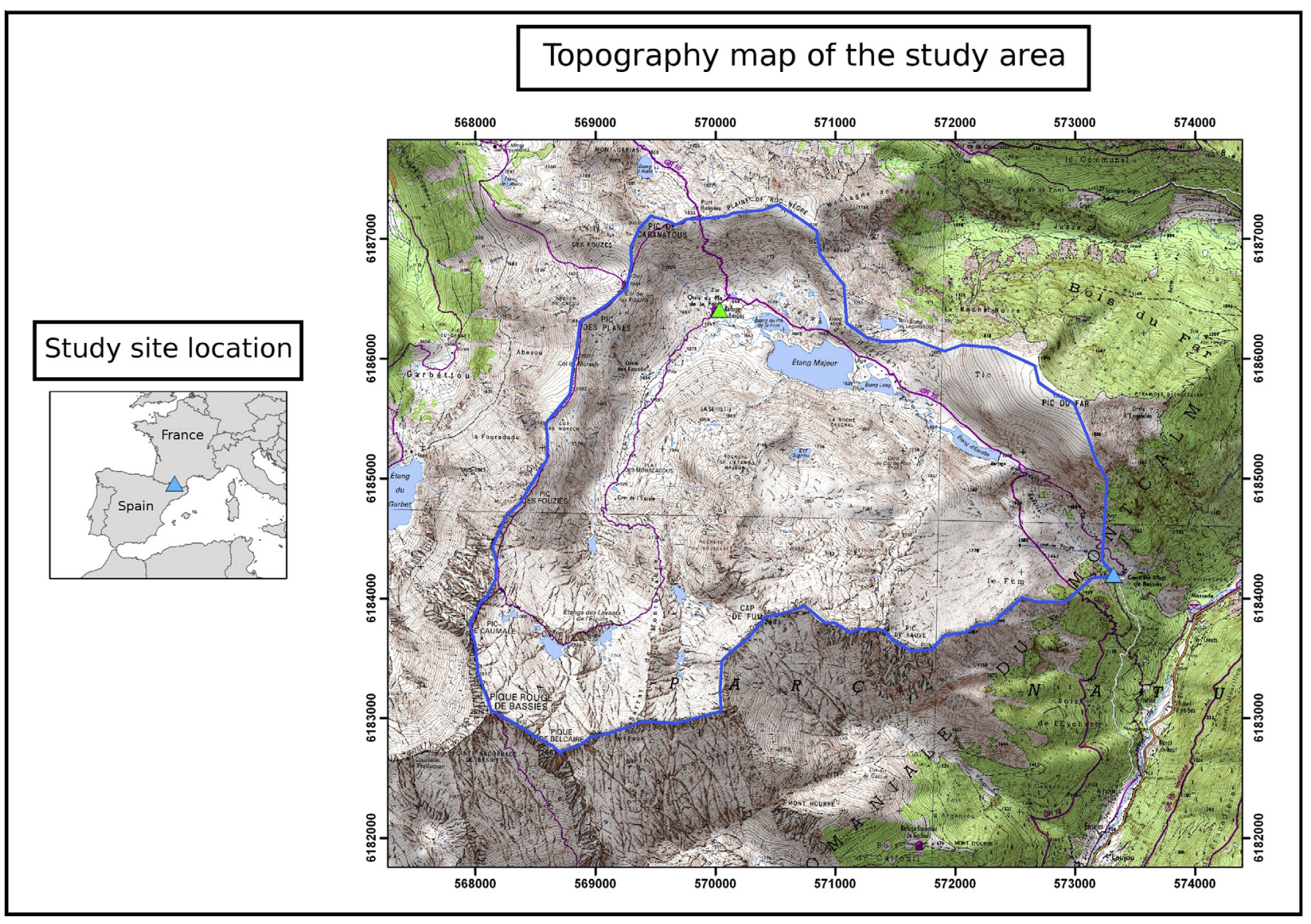

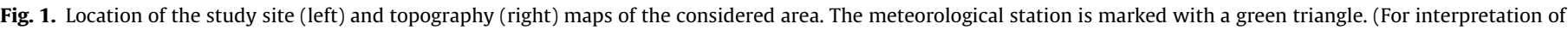
the references to colour in this figure legend, the reader is referred to the web version of this article.) 


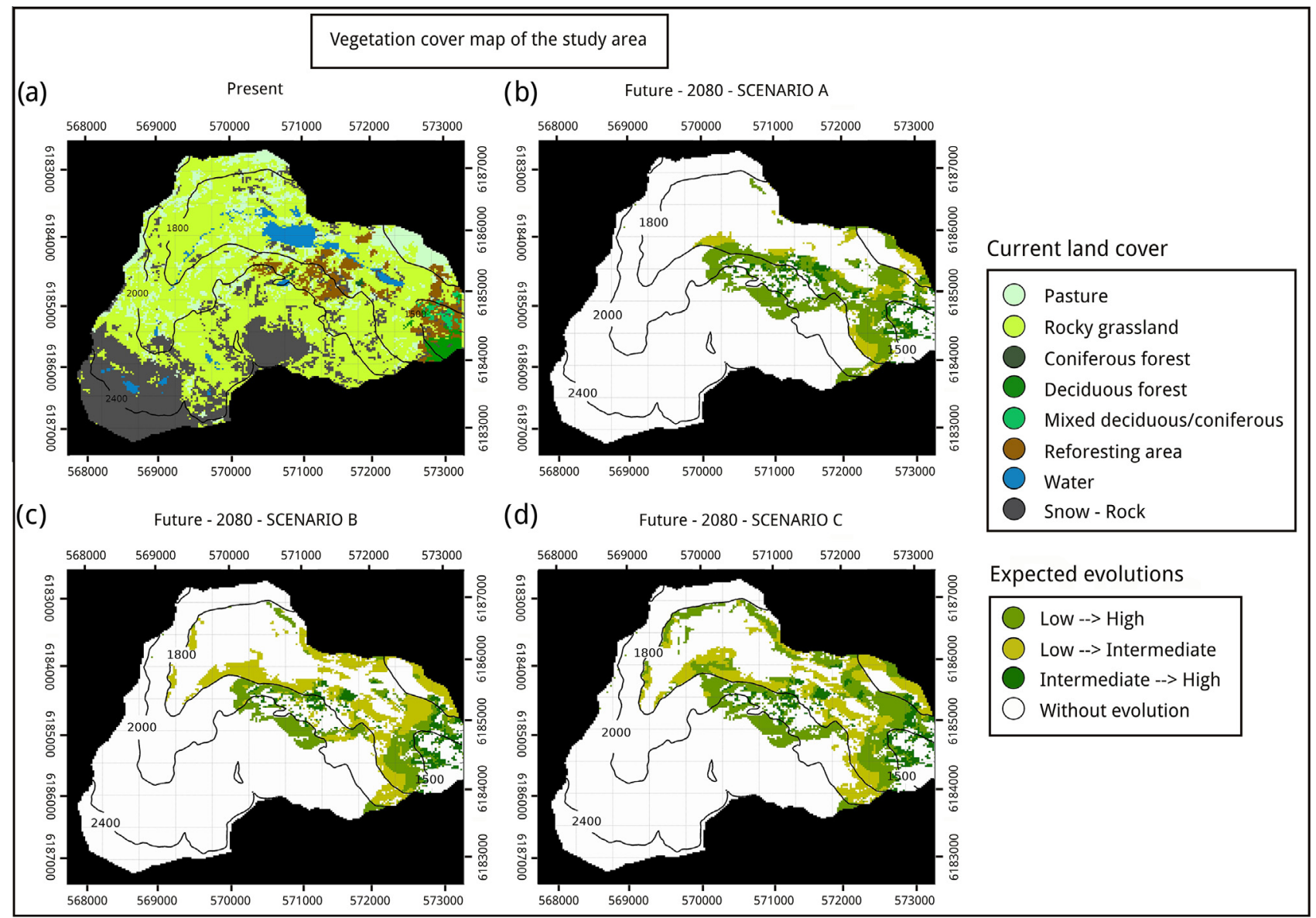

Fig. 2. Current (a) land-use map and future (b, c, d) expected vegetation evolution maps of the Bassiès watershed (Scenario A, B and C, respectively).

Table 1

List of the instruments at the Bassiès station.

\begin{tabular}{ll}
\hline Sensor & Variable \\
\hline $\begin{array}{l}\text { Campbell Sci. HMP45c in unaspirated } \\
\text { radiation shield MET21 }\end{array}$ & Air temperature and humidity \\
Kipp \& Zonen CNR1 & Incoming longwave and \\
& shortwave radiation \\
Young 05103 wind monitor & Wind speed and direction \\
Campbell Sci. SR50A & Snow depth \\
ARG100 Tipping bucket rain gauge & Rainfall \\
\hline
\end{tabular}

the main valley at $1650 \mathrm{~m}$ a.s.l. An independent rain gauge was also installed near the station. During the hydrological year 2012-2013, record snowfalls in the area caused a failure of the instruments during the snow melt season. Therefore, a complete snow season of meteorological data is only available for the hydrological year 2011-2012.

The wind speed measurements were converted to a 2-m height wind speed using a logarithmic wind profile equation and snow depth observations as recommended by Liston and Elder (2006a). Because the rain gauge was not heated, it cannot be used for solid precipitation measurements. Therefore, the snowfall rate was computed from the positive increments in the snow depth measurement time series and converted to water equivalents using the empirical formula of Anderson (1976) for new snow density following the methods of Deems et al. (2008) and Gascoin et al. (2013). These data were used to run SnowModel at an hourly time step. As a first step we did not modify the default precipitation lapse rate in SnowModel because a nearby snow gauge was not available to derive a site-specific lapse rate. The monthly temperature lapse rates were also set to the default values.

\subsection{SnowModel}

SnowModel was used to simulate the snowpack and its temporal evolution on a regular grid over the Bassiès catchment at a spatial resolution of 25 meters over the 2011/2012 snow season.

SnowModel is a spatially distributed snow evolution model (Liston and Elder 2006a; Liston et al., 2007) that resolves the energy and mass balance equations of the snowpack at each time step (here, $1 \mathrm{~h}$ ). SnowModel has already been applied and validated in many areas, including alpine regions with complex terrain (Greene et al., 1999; Liston et al., 2007; Gascoin et al., 2013), and works by coupling four submodels: MicroMet, EnBal, SnowPack and SnowTran-3D. MicroMet is used to distribute the meteorological variables over the model grid to force the other submodels (Liston and Elder, 2006b). EnBal computes the snowpack energy balance (Liston and Hall, 1995; Liston, 1995) and associated runoff (melt water and liquid precipitation). There is no flow routing, SnowPack is a snow depth and snow density evolution model (Liston and Hall, 1995). SnowTran-3D simulates the evolution of snow depth resulting from wind blowing snow, i.e., snow transport and sublimation of windborne snow (Liston et al., 2007). Snow transport by avalanches is not represented. The latest available version of SnowModel was used for this study (last update on 22-01-2013). A complete description of the model structure and summary of the previous applications can be found in Liston and Elder (2006a).

SnowModel uses a land cover map at the same resolution of the digital elevation model. Liston and Elder (2006a) describe in detail the parameterization related to the vegetation processes. SnowModel includes 23 predefined vegetation types, and for each con- 
sidered grid point, a single vegetation type is assigned with an associated canopy height, which defines the vegetation snow-holding depth parameter. The simulated snow depth must to exceed this parameter before snow becomes available for wind transport. Snow falling on a forest grid point is partitioned into interception by the canopy and through fall to the ground. The intercepted amount is determined from the maximum interception storage variable (Hedstrom and Pomeroy, 1998) computed from the effective (which includes stems, leaves and branches, Chen et al., 1997) Leaf Area Index (LAI), which is the case for most of the snow models of the SnowMIP-2 project (Section 1). Two different seasonal LAI values are defined (maximum and minimum) to more accurately describe the vegetation in the summer and winter, respectively (Liston and Pielke, 2001). After deposition, snow can be removed from the canopy by direct unloading, meltwater drip and sublimation. The sublimation of snow held within the forest canopy is described by the influence of the sublimation-loss rate coefficient, the intercepted canopy load and a no-dimensional canopy exposure coefficient (Liston and Elder, 2006a). Moreover, SnowModel defines the melt-unloading rate based on a temperature index method that transfers canopy snow to the ground store where it can be melted. In SnowModel, the snow does not melt while held by the canopy. In contrast with certain models tested in the SnowMIP-2 experiment, the wind influence on unloading canopy-intercepted snow is not included in SnowModel (Roesch et al., 2001; Niu and Yang, 2004).

Regarding the snowpack under the canopy, the top-of-canopy incoming solar radiation is modified in SnowModel according to the Beer-Lambert law following Hellström (2000), which provides a simple bulk canopy transmissivity with an exponential dependence on the LAI (Ross, 1981). The resulting solar radiation (ISR) reaching the snow surface underneath high canopy is reduced and depends on the fraction of ISR transmitted through the canopy, which is particularly linked to the LAI value. This formulation includes the multidimensional character of solar radiation interactions with the canopy, including variations in solar zenith angle (Hellström, 2000). Most snow models considered for the SnowMIP-2 experiment used this simple approach, although some used a two stream approximation (Dickinson, 1983; Sellers, 1985) that allows for scattering and multiple reflections by the canopy between vertical upward and downward radiation fluxes. Turbulent transfers of heat and moisture below the forest canopies and above snowpack involve complex processes that are parameterized by a simple approach (first-order closure). In addition, it considers the 'litter effect' (Section 1) and has separate snow albedo functions for forested and unforested areas (Sproles et al., 2012; Liston and Elder, 2006a).

SnowModel parameters are usually not calibrated because in theory they can be derived from physiographic and climatic data. From a practical perspective, the model uses tens of parameters for each grid cell hence a model calibration is challenging as it is the case for most process-based hydrological models. For this reason, the model was run in a standard configuration with all four submodels activated. All parameters were set to the default value except for the lapse rates for which a separate sensitivity analysis was performed (Section 3).

\subsection{1-D and 2-D validation of SnowModel}

As a preliminary step, in situ and satellite observations were used to evaluate SnowModel's ability to simulate the snow depth and spatial distribution of the snow cover under the current conditions. For this part of the work, SnowModel was run from the 10.11.2011 to the 30.06.2012.

First, the simulated snow depth was compared to the observations at the Bassiès station on an hourly basis.
Then, the four SPOT-4 and one SPOT-5 high-resolution multispectral images were used to assess the quality of the simulations obtained over the watershed (Fig. 3). Multispectral SPOT (Satellite Pour l'Observation de la Terre - Earth Observation Satellite) images are well-suited to the detection of snow cover because they have four spectral bands from visible to short wave infrared (SWIR) at $1.6 \mu \mathrm{m}$. The reflectance of the snow surface is very high in the visible spectrum but drops in the SWIR, which enables the snow surface to be discriminated from other natural white surfaces, such as clouds. Five SPOT images were specifically acquired over the study area on 30.11.2011 (SPOT-5) and 14.01.2012, 16.03.2012, 27.03.2012 and 31.03.2012 (SPOT-4). The initial spatial resolution of the images was $20 \mathrm{~m}$ for SPOT-4 and $10 \mathrm{~m}$ for SPOT-5 $(20 \mathrm{~m}$ for the near infrared band). Data were ordered at Level $1 \mathrm{~A}$ and ortho-rectified using the SIGMA tool, which is a software developed by the Centre National d'Etudes Spatiales (CNES, French Space Agency) to perform satellite image orthorectification, using a reference ortho-image provided by the French Institute for Geography (IGN). The data were resampled to the model grid resolution ( $25 \mathrm{~m}$ ) by cubic convolution and converted to top-of-atmosphere reflectance using the nominal SPOT calibration coefficients. No atmospheric correction was performed; however, at the altitude of the catchment, aerosol optical depths are almost always small in the winter.

We used the Normalized Difference Snow Index (NDSI) to map the extent of snow cover. When the NDSI value is greater than 0.4 , the associated grid point is considered to be covered by snow (Dozier, 1989). The results were plotted for the whole domain and limited areas by considering only the grid cells covered by a defined vegetation type. Four classes were also considered: high vegetation, intermediate vegetation, low vegetation and bare soil. A sensitivity test was as well performed to get insights into temperature and precipitation lapse rate (LR) influence on the simulation. The default monthly temperature lapse rates (TLR) were modified by $+20 \%$ and $-20 \%$ and the default monthly precipitation lapse rates were set to zero. This resulted in a combination of 3 TLR and 2 PLR, i.e a total of 6 simulations, including the simulation with default LR. These simulations were labelled with T0 (default TLR), T1 (LR - 20\%), T2 (LR + 20\%), P0 (default PLR), P1 (PLR=0). We have chosen to test PLR set to zero based on a previous SnowModel study with a similar catchment size (Gascoin et al., 2013). We did not try to decrease the PLR because the results indicated that the model already simulated too much snow in high altitude.

To view the spatial differences, a comparison of the SPOT and SnowModel snow maps is presented for the five SPOT4/5 available dates. Based on the confusion matrix, the accuracy (i.e. proportion of the total number of pixels that were correctly simulated as snow-covered or snow-free) was calculated to analyze the patterns within different threshold altitudes (i.e. with an altitude step of $100 \mathrm{~m})$.

Finally, relationships between altitude, vegetation cover and number of snow-covered days were investigated for SnowModel and SPOT4/5 to compare the percentage of snow cover days according to altitude and land use of a given grid cell, which were obtained from both datasets. The percentage of snow cover days was defined for each pixel as the number of days with snow divided by the number of days.

\subsection{Impact study}

\subsubsection{Climate change}

We used the output of several state-of-the-art Regional Climate Models (RCMs) to get a range of expected near surface air temperature $(T)$ and precipitation $(P)$ changes over our study area. These RCMs were driven by GCMs outputs, which provided the boundary conditions at global scale ("ocean scenario"). The resolution of the 


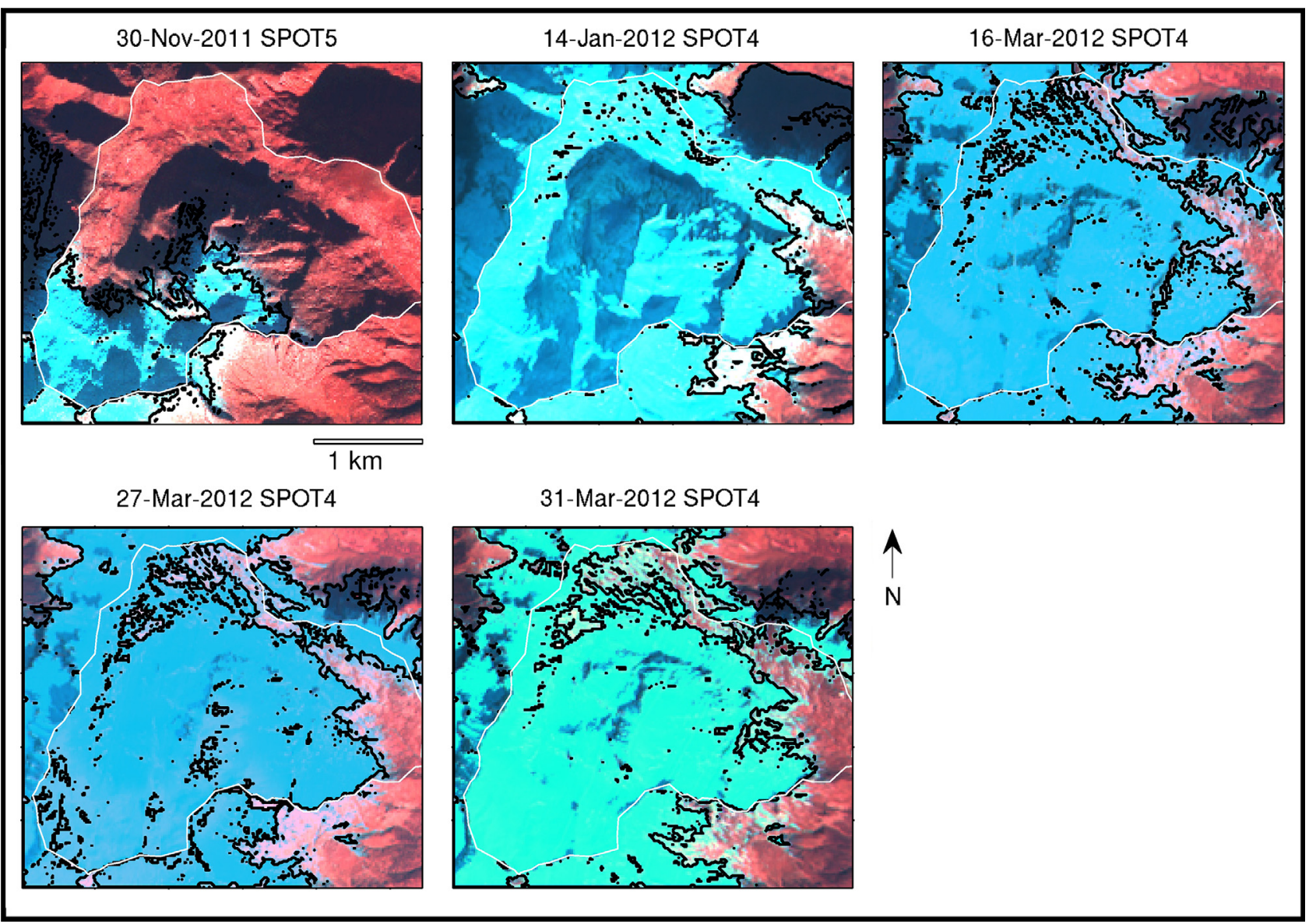

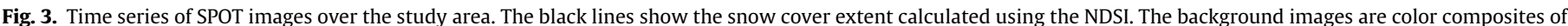

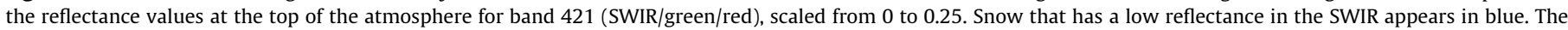

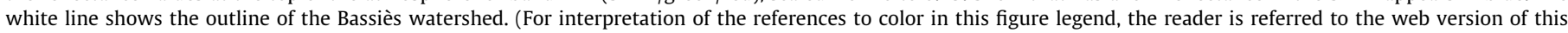
article.)

RCMs is $12-\mathrm{km}$, which is already a high resolution for climate models, yet it is insufficient to be used for our study catchment $\left(14.5 \mathrm{~km}^{2}\right)$. For this reason, it was necessary to further downscale the climate model projections using the local meteorological observations. We applied a standard anomaly method (or delta method), which is often used in climate change impact studies to downscale climate models outputs (Fowler et al., 2007). We extracted the departures in $\mathrm{T}$ and $\mathrm{P}$ computed between the reference period (1971-2000) and the future period (2071-2100) for the RCM's grid cell located above our study area on a monthly basis. The monthly mean departures obtained from all the available $\{\mathrm{RCM}$; Emission scenario combinations were then applied to our in situ meteorological dataset (1-year) in order to generate a range of new climatic forcing of 1-year. By using this method, we compared a 1-year simulation (2011-2012) with different other 1-year simulations (future climate). This method is simple but eliminates a possible bias in the climate model with respect to the study area. It is aimed at allowing a rough assessment of the sensitivity of the model to a "realistic" change of the climate. However, it does not account for the natural climate variability since we used only one year of in situ data. More sophisticated downscaling methods could not be applied here because the meteorological record was too short. However, previous studies indicated that the main uncertainty in climate change impact studies is associated with the GCM (e.g., Habets et al., 2013). Temperature and precipitation anomalies were extracted from the output of the SCAMPEI project climate models (http://www.cnrm.meteo.fr/ scampei/).
Table 2

Summary of the SCAMPEI temperature and precipitation scenarios used in this study.

\begin{tabular}{lll}
\hline & ALADIN & LMDZ \\
\hline \multirow{2}{*}{$2021-2050$} & A1B (ALD1), & A1B IPSL-SST (LMD1), \\
& A2 (ALD2), B1 (ALD3) & A1B CNRM-SST (LMD2) \\
$2071-2100$ & A1B, A2, B1 & A1B IPSL-SST, A1B CNRM-SST \\
\hline
\end{tabular}

The SCAMPEI project has developed an original technique for producing daily series describing French climate over three time slices (past, near future, and far future) as a function of the geographical position and altitude (Rousselot et al., 2012). In SCAMPEI, the dynamical downscaling is based on three 30-year simulations: 1961-1990 (past reference), 2021-2050 (near future), 2071-2100 (end of the century). In this study, only the far future periods 2071-2100 was used from the following RCMs: (i) ALADIN (Aire Limitée, Adaptation Dynamique pour la coopération Internationale, Radu et al., 2008; Colin et al., 2010) and (ii) LMDZ (Goubanova and Li, 2007) and (iii) MAR (Fettweis et al., 2007). ALADIN, which was developed in Météo-France, was run with the three greenhouse gas scenarios (A1B, A2 and B1, Le Treut, 2003). A regional version of the LMDZ, which is the atmospheric Global Climate ModelGCM developed at the LMD (Laboratoire de Météorologie Dynamique), was used in the SCAMPEI project and run with the greenhouse gas scenario $\mathrm{A} 1 \mathrm{~B}$ and with two different boundary conditions (called "ocean scenarios"), one generated by the CNRM/MétéoFrance (Centre National de Recherches en Météorologie) and the second by the IPSL (Institut Pierre Simon Laplace). These five monthly temperature and precipitation scenarios, indexed in the 
Table 3

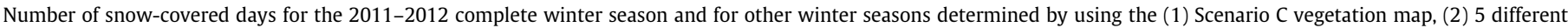

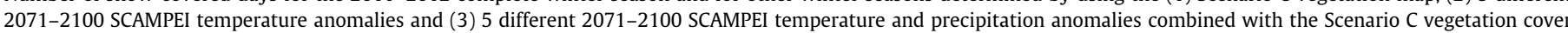
map. These results were computed at the Bassiès station and over the whole basin (Mean1).

\begin{tabular}{|c|c|c|c|c|c|c|c|c|c|c|c|c|}
\hline & 2011-2012 & New Veg & $\mathrm{T} 1$ & $\mathrm{~T} 2$ & T3 & $\mathrm{T} 4$ & $\mathrm{~T} 5$ & $\mathrm{~T} 1+\mathrm{P} 1+\mathrm{Veg}$ & $\mathrm{T} 2+\mathrm{P} 2+\mathrm{Veg}$ & $\mathrm{T} 3+\mathrm{P} 3+\mathrm{Veg}$ & $\mathrm{T} 4+\mathrm{P} 4+\mathrm{Veg}$ & $\mathrm{T} 5+\mathrm{P} 5+\mathrm{Veg}$ \\
\hline Station & 180 & 180 & 124 & 111 & 141 & 104 & 122 & 123 & 109 & 141 & 103 & 121 \\
\hline Mean basin 1 & 204 & 203 & 169 & 158 & 181 & 156 & 172 & 167 & 157 & 180 & 156 & 175 \\
\hline
\end{tabular}

Table 2, are used in this study to change the 2011-2012 hourly temperatures and precipitations and to run SnowModel to show the impact on the snow cover.

\subsubsection{Land cover changes}

Three scenarios of land cover changes are used that were generated using the Land Change Model (LCM) (Eastman, 2009), which is an inductive pattern-based model (Mas et al., 2014) used to simulate the patterns of land use and land cover change. It does not simulate vegetation growth processes as would do a process-based model. Based on two land cover maps (1983 and 2008) and past observed changes (Houet et al., 2012), the LCM estimated future land cover changes using probabilistic Markov chains to estimate future LUCC (Land-Use and land-Cover Change) trends. The scenarios were computed up to 2080 and assumed that the anthropogenic pressure will be maintained over time. The spatial allocation procedure of land cover change is described in the literature (Eastman, 2009) and was used to integrate geographical driving forces and plan land use strategies. While agro-pastoral activities explain mountainous open landscapes, paleo-environmental and historical data have shown that natural landscapes over the study site should be largely composed by forests and shrubland (Galop and Jalut, 1994). Therefore, the allocation of agro-pastoral activities would largely depend on geographical (altitude, exposure, slopes, distance from land cover type, etc.) and climatic (temperature, rainfall, etc.) drivers. LCM integrates all of these geographical drivers. It spatially estimates their respective weight using a neural network (Multi-Layer Perceptron) for each user-defined land cover transition. For the purpose of this study, we retained only the major transitions (greater than $100 \mathrm{ha})$ observed from past land cover maps to project future changes. Regarding agro-pastoral activities and trends of herd size (number of sheep, cows and horses), various options of land uses can be implemented in the modeling and applied over the whole Vicdessos Valley: (i) Scenario A does not include a land use strategy; it is assumed that LCM is able, based on the LUCC trends, to detect where the future changes may occur; (ii) Scenario B assumes a 'business-as-usual' strategy, where current pastoral pressure within the pastoral areas that are defined and declared to the pastoral administration to get European subsidies are pursued; (iii) Scenario C assumes a 'selective' strategy where only certain pastoral areas would be supported because they help to maintain an open landscape and have high agronomical properties. The Bassiès catchment is currently part of a pastoral area that exhibits a low pastoral pressure, and only $15 \%$ of resources are used from animals placed in this area. Due to this low pastoral pressure, the Bassiès area was no longer dedicated to pastoral uses in the future.

Forests cover $2 \%$ of the Bassiès catchment in 2008. Considering the suitability of the Bassiès area to future LUCC due to pastoral pressures defined in Scenarios A, B and C, the simulations made over the whole Vicdessos study site lead to various forests proportions in the Bassiès basin of $19 \%, 15 \%$ and $22 \%$, respectively. New forests would be comprised of conifers. Intermediate vegetation (small trees) covers $5 \%$ of the Bassiès catchment and represents $4 \%, 12 \%$ and $11 \%$ of the basin in the scenarios $A, B, C$, respectively.
In addition, a fourth scenario was considered in which the study area is completely reforested by conifers except in the areas classified as surface water or bare rock, which is $74 \%$ of the catchment. This more extreme scenario permits a more accurate understanding of the model sensitivity to vegetation changes.

\subsubsection{Simulations}

We performed the simulations for all the different climate and land cover scenarios. Only land cover scenario $C$ (which is considered to be the most probable) was selected to generate five combined climate and land cover scenarios from all the available SCAMPEI scenarios. The results were analyzed in terms of snow depth, number of snow days and the main terms of the snowpack mass balance equation. The number of days was computed at different scales by using different approaches:

- Point-scale approach (1-D): considers only the number of snow covered days at the Bassiès station.

- Catchment-scale approach (2-D): computes the number of snowcovered days for each grid cell over the whole 2011-2012 snow season and the average number of snow-covered days to determine the mean number of snow-covered days obtained over the Bassiès catchment for a winter period (referred to as Mean 1 in Table 3).

Finally, to better understand the influence of temperature and vegetation variables on SnowModel simulations, selected components of the simulated snowpack budget were compared on a monthly basis at the scale of the Bassiès catchment and included sublimation processes (static sublimation and blow sublimation), wind transport, canopy unloading and snowmelt runoff.For this second part of the work, SnowModel was run from the 10.11.2011 to the 30.09.2012.

\section{Results and discussion}

\subsection{Validation of SnowModel snow depth simulations}

\subsubsection{Evaluation at the Bassiès station}

Fig. 4 presents a comparison of the temporal evolution of the snow depth simulated by SnowModel and those observed between November 2011 and July 2012 at the Bassiès station. The model was able to reproduce the snow depth at the station location over this period, and this was previously demonstrated in several SnowModel applications (Liston et al., 2007). Some differences were observed between the two data sets during the snowmelt (RMSE) but remain within the range of discrepancies that are typically observed between snowpack model simulations and observations in open areas (see the SnowMIP experiment, Etchevers et al., 2004). The version of the model used in this study has different parameters set by default, and no specific parameterizations were performed for this study case. For this reason, the differences observed between the simulations and the observations can be considered to be low. 


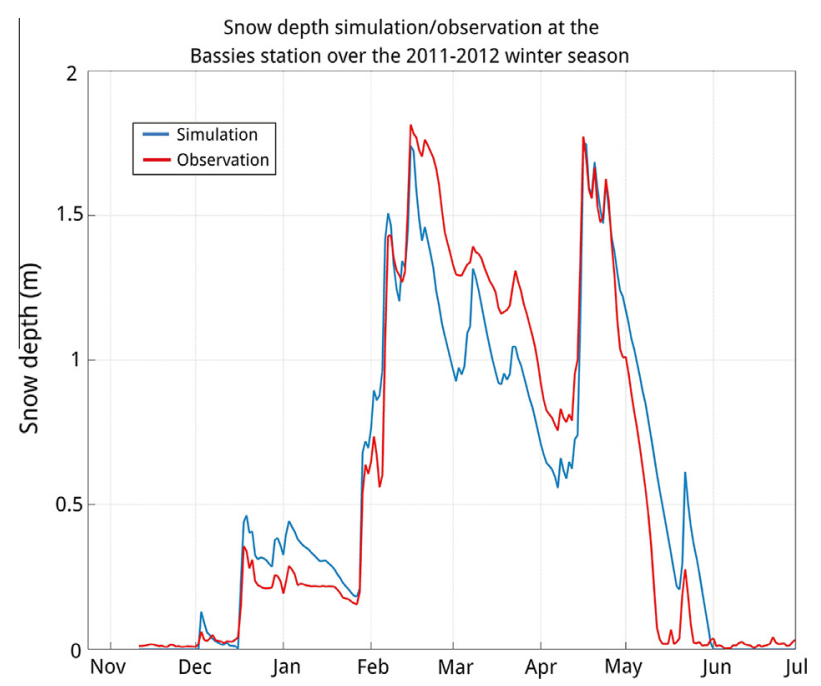

Fig. 4. Temporal snow depth evolution at the Bassiès station simulated by SnowModel (blue line) and observed (red line), over the entire 2011-2012 winter season. (For interpretation of the references to color in this figure legend, the reader is referred to the web version of this article.)

\subsubsection{Evaluation over the whole watershed}

Fig. 5 shows a comparison between the simulated snow cover area and snow cover area computed from SPOT images. We considered the whole domain (Fig. 5a) and only included the grid cells covered by (1) high vegetation (Fig. 5b), (2) intermediate vegetation (Fig. 5c), (3) low vegetation (Fig. 5 and (4) bare soil (Fig. 5e). The snow-covered surface area fraction is plotted for the entire 2011-2012 winter season for the SnowModel simulations and the 5 available dates for SPOT4 and SPOT5. Fig. 5 shows that the fraction of snow-covered surface area is positively biased with regards to the remote sensing observations; however, it is interesting to see that the evolution of this percentage, particularly in March, is similar for both data sets over time. This result holds for the different vegetation types except bare soil, for which the evolution in March is not consistent between the two data sets. This result occurs most likely because bare surfaces correspond to steep rock faces in this area and there is a lack of representation in SnowModel of the physical accumulation processes in more sloping areas. Fig. 6 shows the spatial distribution of snow obtained with SnowModel for each of the 5 SPOT4/5 available dates (Fig. 3). Fig. 6f presents the accuracy computed between the two datasets for altitude thresholds of $100 \mathrm{~m}$ (from $900 \mathrm{~m}$ to $2700 \mathrm{~m}$ ). It shows that most of the pixels which were incorrectly simulated as snow-covered are located near the snowline eleva-
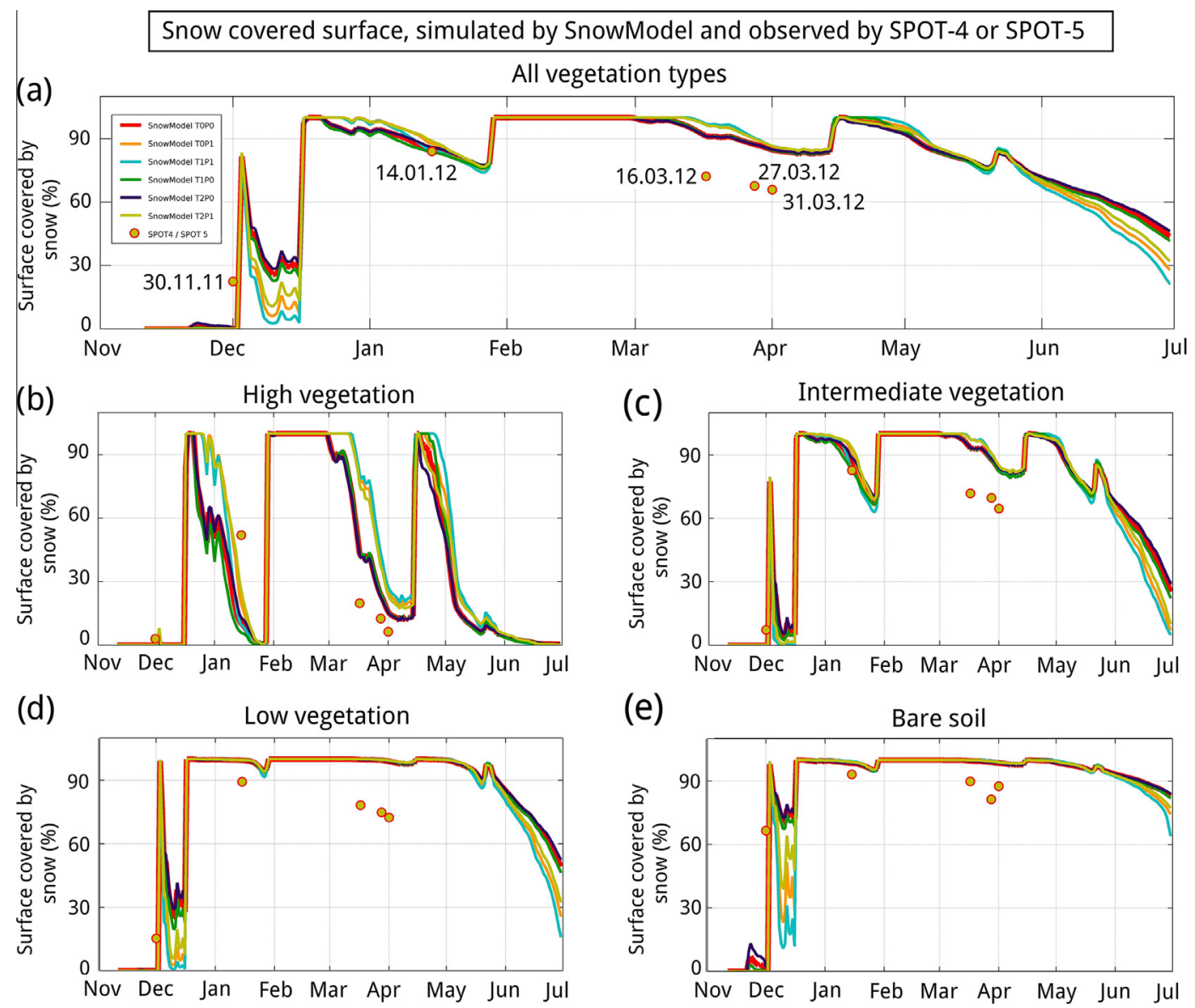

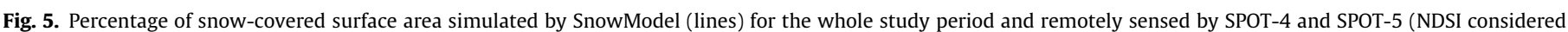

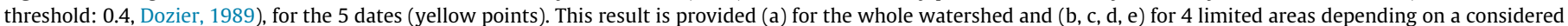

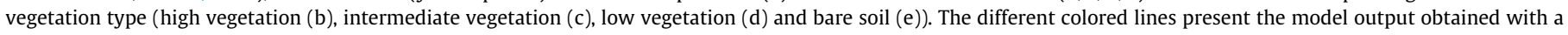

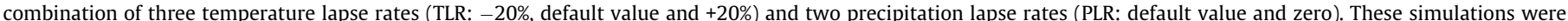

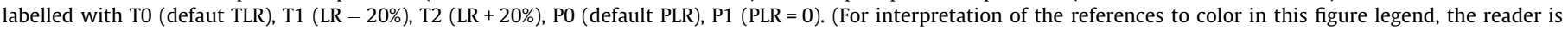
referred to the web version of this article.) 


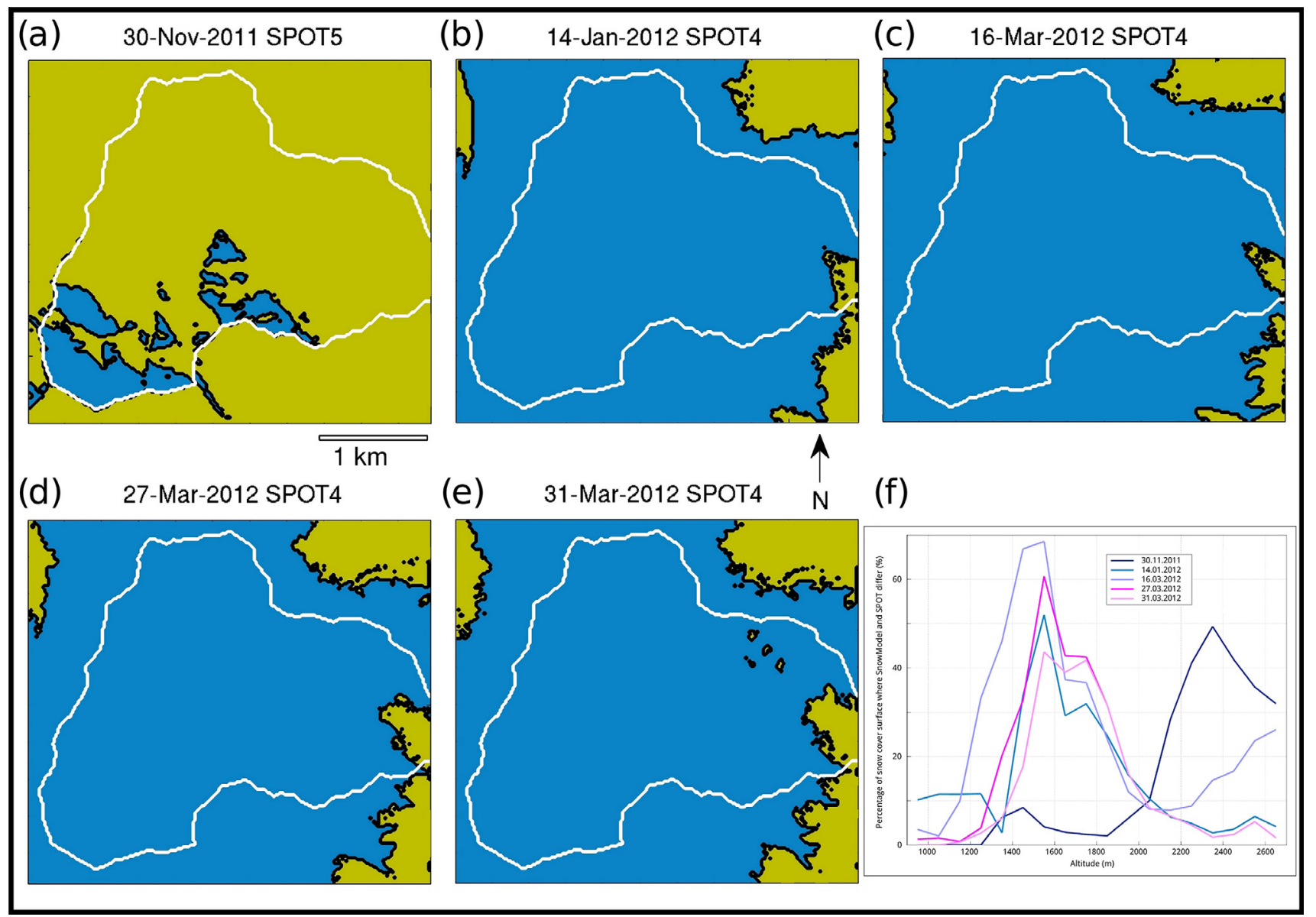

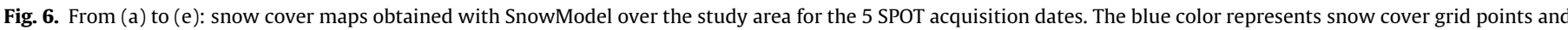

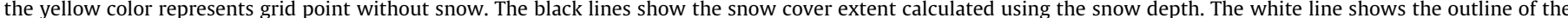

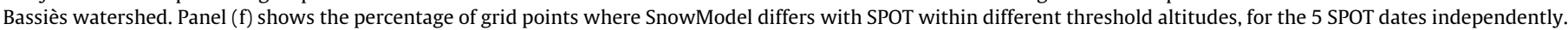
(For interpretation of the references to color in this figure legend, the reader is referred to the web version of this article.)

tion. For the 30th November 2011 (SPOT5), the snow cover is distributed in a limited area, in high altitudes, which explains why the differences are observed in high altitude (Fig. 6f). For the four other dates, the snowline is located at lower altitudes and thus the greater differences are obtained for the altitudes ranged between 1300 and $1800 \mathrm{~m}$.

We then specifically addressed the model's ability to describe the link between altitude, land cover and number of snow days over the study area using the same remote sensing snow cover maps (Fig. 7). Both data sets appeared consistent in terms of the relationship between (1) altitude and number of snow-covered days (Fig. 7a and b.) and (2) vegetation cover and percentage of snow cover days (Fig. $7 \mathrm{~d}$ and e). When the altitude was higher, the number of snow days was greater because of the lower temperatures at higher altitudes in winter (top row of Fig. 7). If the relationship between both variables was linear and gradual with the SPOT-4/SPOT-5 data, then snow was rarely found under $1800 \mathrm{~m}$ and often occurred during the winter season above $1800 \mathrm{~m}$ with SnowModel. The Fig. 7c shows the link between land cover type and altitude. Higher vegetation is found at lower altitudes. In high altitude, the land cover is mainly bare soil. As mentioned above, the present-day land cover is largely governed by the catchment topography. Therefore, to compare the snow cover response that is specific to the land cover, it was necessary to remove the first order influence of elevation on the snow cover duration (the relation between these two datasets appears in the Fig. 7a). This was performed by fitting a linear function using a least-square method between the number of days with snow and elevations for each pixel. Then, the residuals of this regression (percentage of snow cover days) were plotted against the vegetation types (bottom row of Fig. 7). Again, both data were consistent. When the vegetation was higher, the snow cover probability was lower and conversely. It showed that the land cover had a similar impact on the snow cover both in the SnowModel simulation and the satellite observations, such that high vegetation tended to reduce the mean snow duration.

\subsection{Model projections}

The main objective of this study was to quantify the impact of climate and land cover change on snow accumulation and ablation. Those two changes were first studied independently to better understand how they affect the different steps of the hydrological cycle related to the snow variable. Then, the different expected changes were considered together.

\subsubsection{Impact of the land cover changes on snow depth at the catchment scale}

Fig. 8 presents the mean monthly snow depth evolution simulated by SnowModel with the current land cover map and averaged over the whole Bassiès catchment for the 2011-2012 winter season. The mean monthly snow depth obtained by the three different 2080 expected land cover maps (Scenarios A, B and C) are also plotted in this figure. Differences between the current and future 


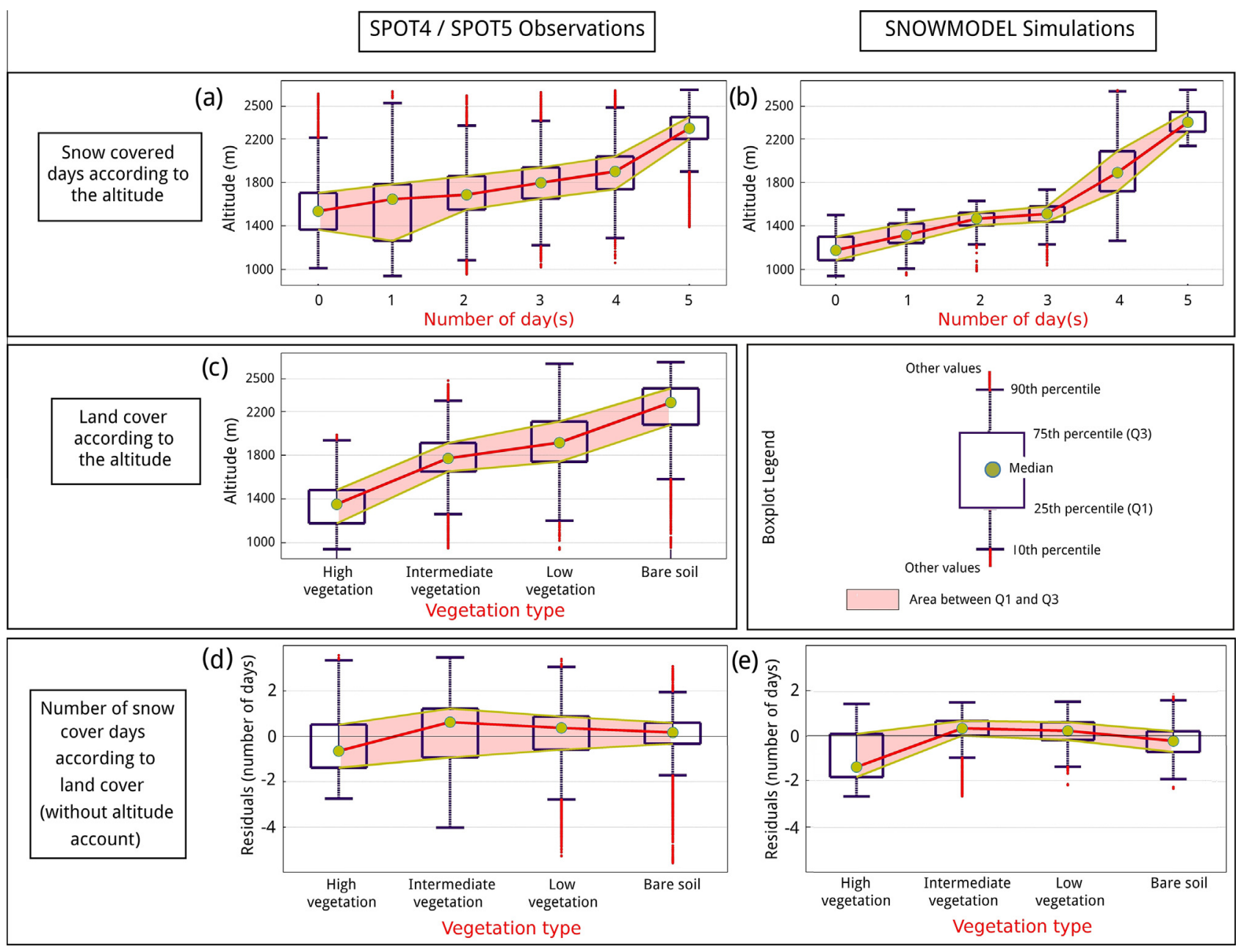

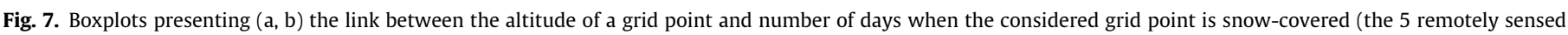

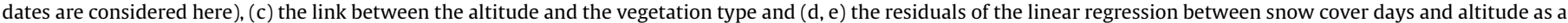
function of the land cover (left) observed by SPOT-4 and SPOT-5 and (right) simulated by SnowModel.

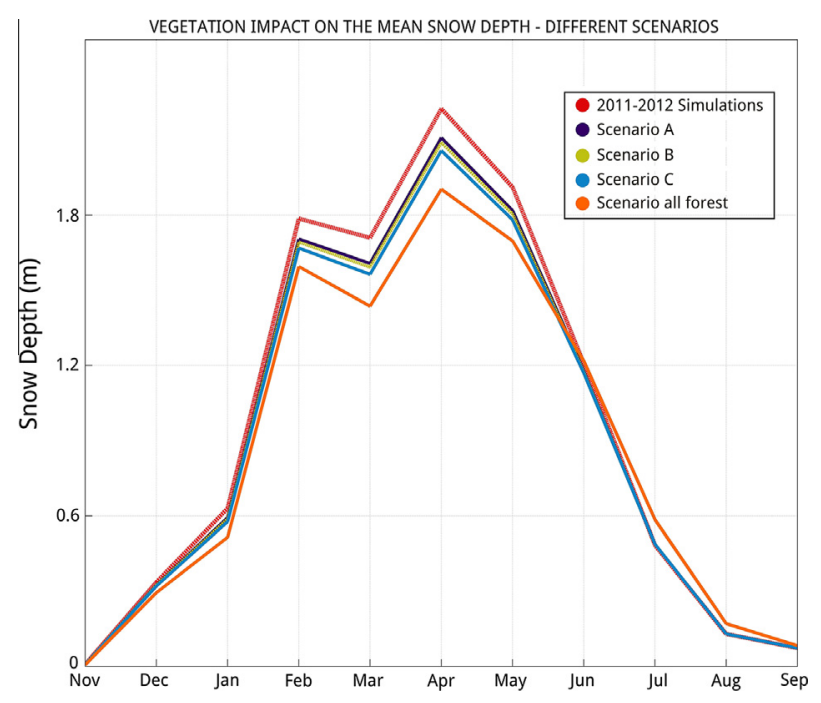

Fig. 8. Comparison of the evolution over time of the mean monthly snow depth simulated by SnowModel with the 2011-2012 meteorological data with the (1) current vegetation map, those simulated with (2) the 3 new expected vegetation maps (scenarios A, B and C) and the last obtained by using (3) a land-use map exclusively covered by forest excepted on the rock and water areas. The snow depth values are averaged over the whole considered catchment. expected conditions were observed during the accumulation and ablation stages. During the accumulation period, the projected snow depths were lower than the reference for all the land cover scenarios (Fig. 8). Fig. 8 shows that the mean snow depth obtained on the soil surface during the different snowfall events was also smaller when the percentage of forest in the catchment was greater for the three scenarios. During the ablation phase, the snow depth decreased more slowly under high vegetation when compared to the snow depth simulations obtained with the current land cover map.

Scenario A has $19 \%$ forests but higher snow depth than scenario B (15\% forests). This is because intermediate vegetation has the same effect on the snow cover than the high vegetation on the snow deposition and snow melt in SnowModel. The scenarios A, $\mathrm{B}$ and C have respectively $23 \%, 27 \%$ and $33 \%$ of intermediate and high vegetation (Section 2.5.2). The results from the scenario "all forest" confirmed that the snow accumulation on the surface was reduced by the presence of deciduous forest. Indeed, the obtained snow depth was smaller at the beginning of the snow season and after the snow accumulation phase between February and April. Even if the case considered here affected a significant portion of the deposition stage, the snowmelt was so much slower in this snow depth scenario that the snow disappeared later on average over the considered area in the winter season. 

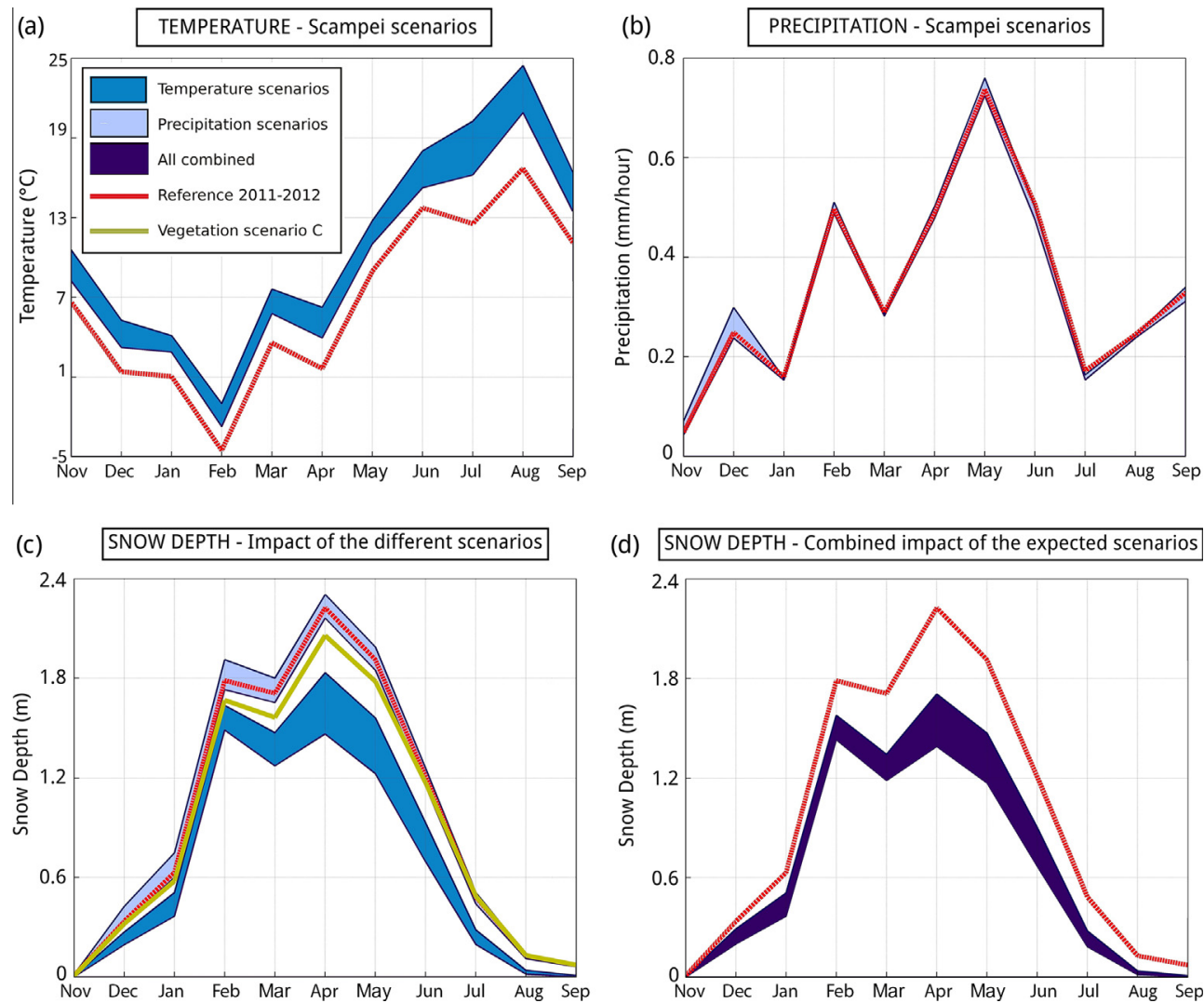

(d) SNOW DEPTH - Combined impact of the expected scenarios

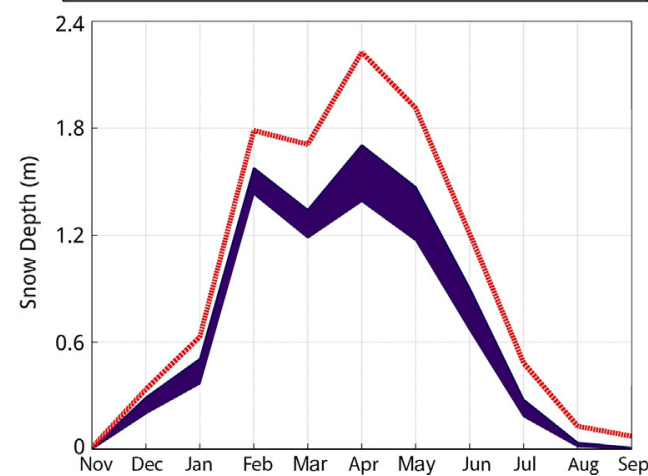

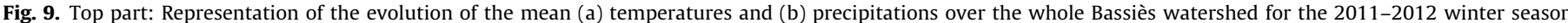

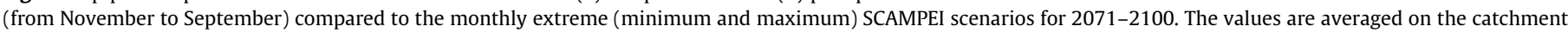

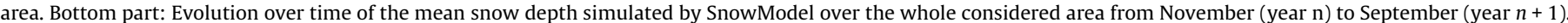

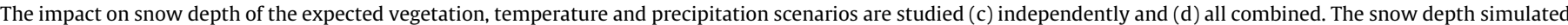

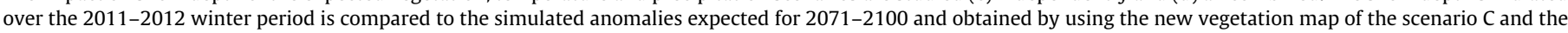
five SCAMPEI scenarios, respectively. Only the monthly extreme (minimum and maximum) snow depth are plotted here (also catchment-scale averages).

\subsubsection{Impact of climate and land cover changes on snow depth at the} catchment scale

Fig. 9a and b shows, respectively the mean monthly expected (1) temperature and (2) precipitation changes over the Bassiès catchment for a snow season up to the 2080 period. The five SCAMPEI scenarios are considered in this figure and both minimum and maximum of the monthly (1) temperature and (2) precipitation of the 5 scenarios, respectively, are represented at the top of the figure (Fig. 9a and b). Fig. 9a shows that a relative homogeneous increase of the mean monthly temperature is expected over the Bassiès basin for all the five scenarios. Regarding the precipitation (Fig. 9b), the range and the magnitude of the expected change is lower, although high elevation precipitation is usually characterized by a high variability between climate projections, and not similar over time from one month to another for a given SCAMPEI scenario. The sign of the expected evolution also varies from one SCAMPEI scenario to another. Fig. 9c presents the consequences of these expected temperature and precipitation conditions on the mean monthly snow depth, which was averaged for the Bassiès catchment. The impact of the land cover scenario C (Fig. 8) on the snow depth is also represented. The consequences of all the changes were considered independently (Fig. 9c) and then combined (Fig. 9d). The independent analysis showed that the temperature change will generate the greatest impact on the snow depth when compared to vegetation and precipitation changes, particularly during the snow accumulation phase. With the temperature increase, the snow deposition will be decreased on average over the catchment. The spread in the projected evolution of the snow depth due to different the climate scenarios is reduced during the snow melt period. By combining the effect of the three variable changes, the impact on the mean snow depth was still bigger, and the mean monthly snow depth computed over the whole catchment was significantly decreased in comparison to the current situation.

This is reported in Table 3, which presents the number of snow covered days for a standard snow season that are (1) currently observed and compared to (2) the different expected scenarios at the Bassiès station and over the whole catchment. At the station, the expected vegetation change did not impact the duration of snow cover, whereas the temperature change decreased the snow cover duration on average by $33 \%$ (Table 3 ). By combining the effect of vegetation, precipitation and temperature, the impact was not greater than those obtained by changing only the temperature. Similar results were obtained over the whole basin by considering Mean1, in which the impact of temperature change on the snow cover duration is more limited and represented $18 \%$ of decrease.

\subsubsection{Impact of climate and land cover changes on the spatial distribution of the snow depth}

Fig. 10 presents the spatial evolution of the snow depth averaged over a standard snow season (November to September, Fig. 10a) and simulated between the current and future expected situations (Fig. 10b-f). The differences were first plotted by only considering the 5 SCAMPEI expected temperature changes. Only the extremes (greatest - Fig. 10b - and smallest - Fig. 10c - differ- 
(a)
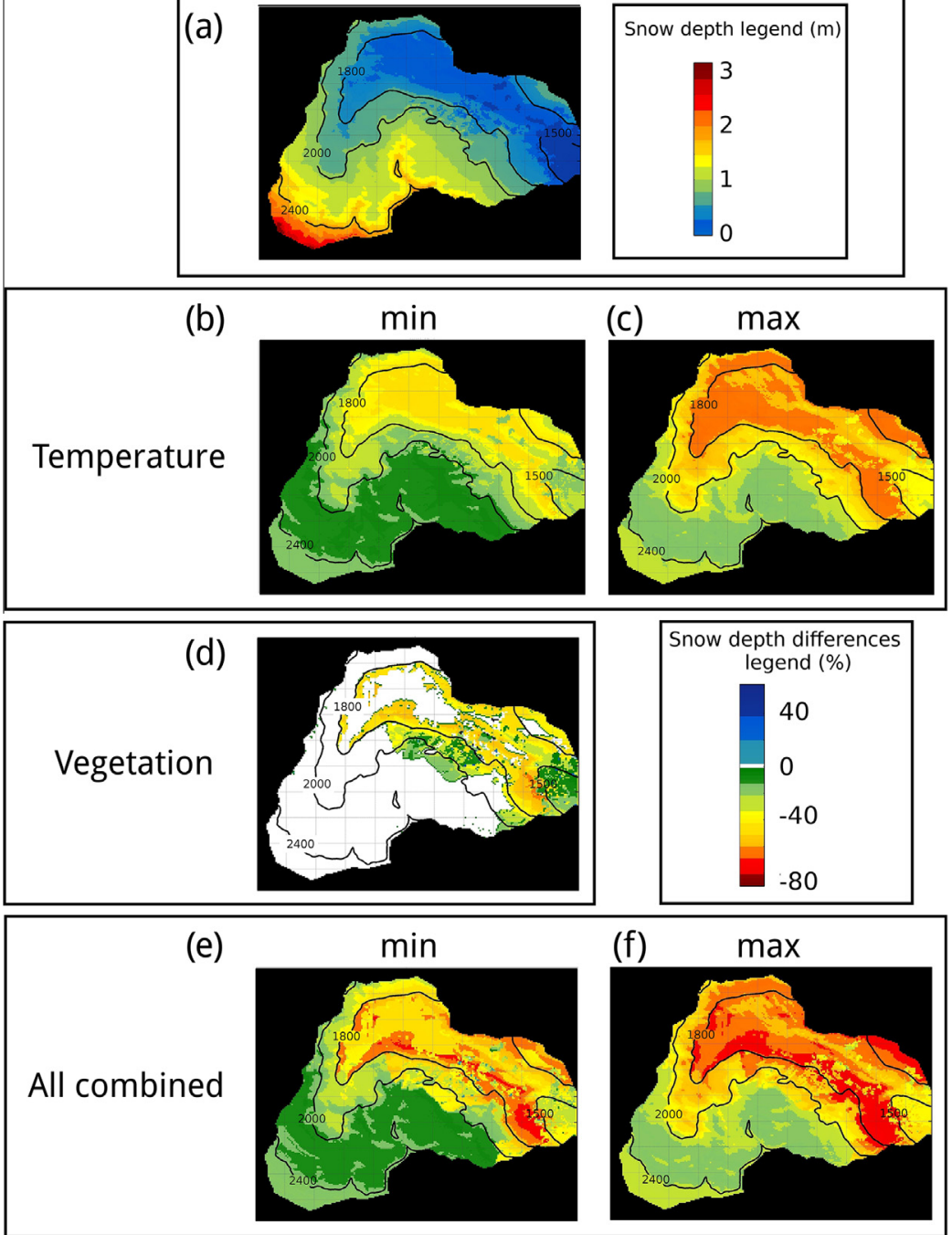

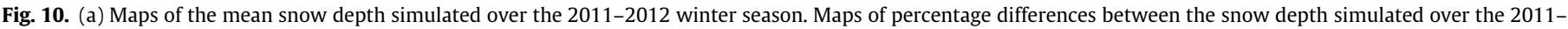

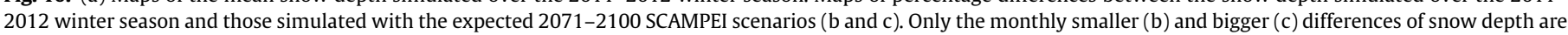

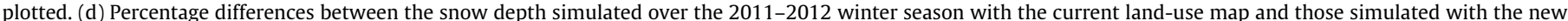

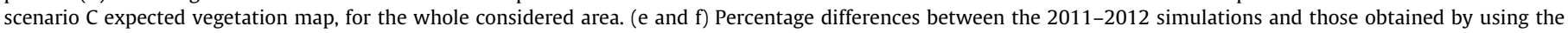

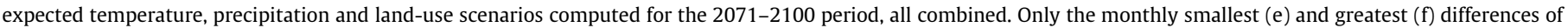
snow depth are plotted.

ences) appear in this figure. The largest differences were obtained in the area between 1500 and $2000 \mathrm{~m}$ a.s.l (Table 4). Over these areas, the observed average wintertime air temperature was close to zero over the reference period; therefore, an increase of this variable directly decreases the fraction of snow in the total precipitation. For the areas above $2000 \mathrm{~m}$ a.s.l. and under $1500 \mathrm{~m}$ a.s.l., the impact of temperature was more limited (Table 4), because the temperature changes are not sufficient to modify the precipitation phase. The same analysis was performed between the current land cover and scenario C (Fig. 10d) and showed that an evolution of low vegetation (grassland or subalpine meadow) in intermediate or high vegetation (scattered short conifer or forest) generated a mean snow depth decrease of $42 \%$. The general evolution of intermediate vegetation to high vegetation tended to decrease the simulated snow depth by $8 \%$ on average. More importantly, areas where the land cover changes (see Fig. 2) were expected to occur matched the areas where the impact of changing temperature on snow depth should be the greatest (in the northeastern part of the catchment area, Fig. 10). For this reason, by combining the effect of air temperature, precipitation and land cover on the snow depth (Fig. 10e and f), the snow depth tended to decrease to $70 \%$ in areas situated between 1500 and $2000 \mathrm{~m}$ a.s.l. (Table 4). Areas located above $2000 \mathrm{~m}$ a.s.l. were not significantly affected, and the snow depth decrease was comparable to those obtained by changing only temperatures (Table 4).

\subsubsection{Impact of climate and land cover changes on the snowpack mass} budget components

Static sublimation, canopy unloading, wind transport, blowing snow sublimation, canopy sublimation and runoff were represented to decipher the impact of the climate and land cover change on these components (Fig. 11). Canopy sublimation and blowing snow sublimation were found to be negligible and were not represented. Runoff from snow melt was by far the largest contributor to the snowpack ablation. The sublimation (Fig. 11a) represented less than $1 \%$ of the total ablation. Canopy unloading (Fig. 11b) was also very low $(0.24 \%)$. Therefore, even if the percentage of the three variable expected evolutions appeared to be significant (Fig. 11), the actual water balance would not be impacted. 
Table 4

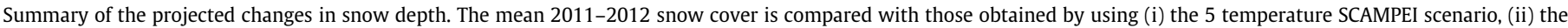

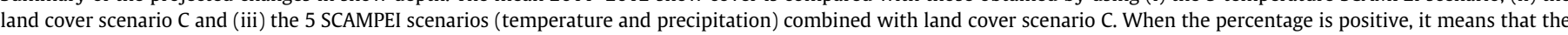
snow depth is reduced in the future. Only the mean, the minimum and the maximum are reported in this table.

\begin{tabular}{|c|c|c|c|c|}
\hline Impact study & Altitude range & $\begin{array}{l}\text { Mean difference obtained } \\
\text { with the } 5 \text { scenarios (\%) }\end{array}$ & $\begin{array}{l}\text { Smallest difference obtained } \\
\text { with one of the } 5 \text { scenarios (\%) }\end{array}$ & $\begin{array}{l}\text { Greatest difference obtained } \\
\text { with one of the } 5 \text { scenarios (\%) }\end{array}$ \\
\hline Temperature impact & $\begin{array}{l}<1500 \mathrm{~m} \text { a.s.l. } \\
{[1500 ; 2000] \mathrm{m} \text { a.s.l. }} \\
>2000 \mathrm{~m} \text { a.s.l. } \\
\text { Entire watershed }\end{array}$ & $\begin{array}{l}32 \\
45 \\
17 \\
38\end{array}$ & $\begin{array}{l}22 \\
37 \\
11 \\
25\end{array}$ & $\begin{array}{l}35 \\
55 \\
21 \\
41\end{array}$ \\
\hline Vegetation impact & $\begin{array}{l}<1500 \mathrm{~m} \text { a.s.l. } \\
{[1500 ; 2000] \mathrm{m} \text { a.s.l. }} \\
>2000 \mathrm{~m} \text { a.s.l. } \\
\text { Entire watershed }\end{array}$ & & $\begin{array}{l}3 \\
23 \\
1 \\
10\end{array}$ & \\
\hline $\begin{array}{l}\text { All changes combined (temperature, } \\
\text { precipitation and vegetation) }\end{array}$ & $\begin{array}{l}<1500 \mathrm{~m} \text { a.s.l. } \\
{[1500 ; 2000] \mathrm{m} \text { a.s.l. }} \\
>2000 \mathrm{~m} \text { a.s.l. } \\
\text { Entire watershed }\end{array}$ & $\begin{array}{l}40 \\
60 \\
21 \\
52\end{array}$ & $\begin{array}{l}33 \\
55 \\
14 \\
44\end{array}$ & $\begin{array}{l}44 \\
70 \\
25 \\
62\end{array}$ \\
\hline
\end{tabular}
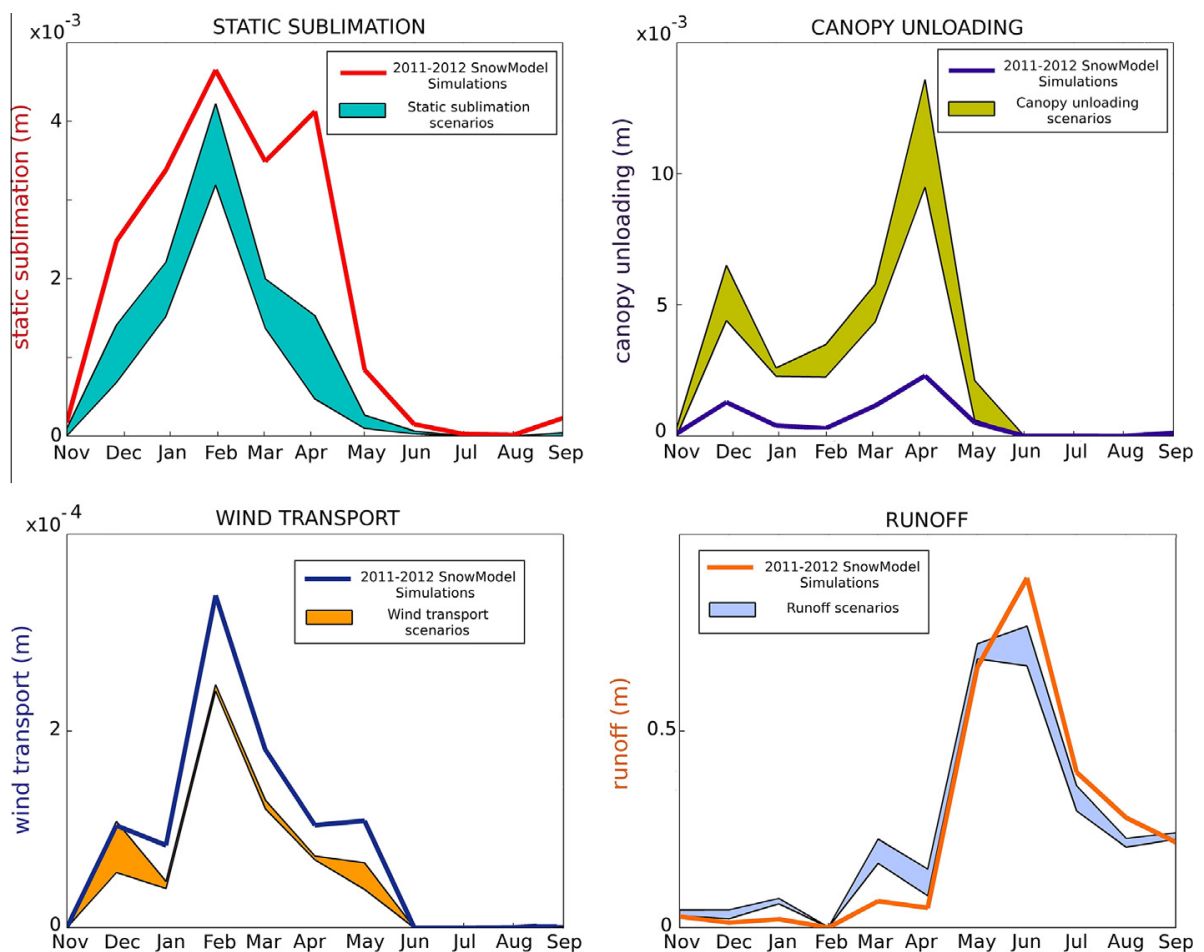

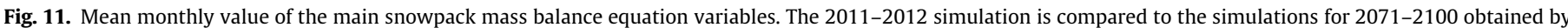

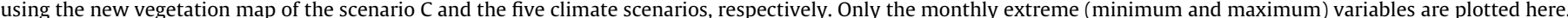

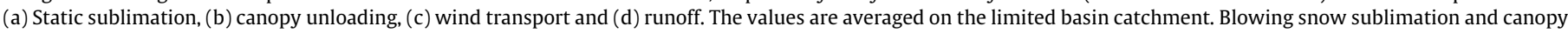
sublimation are negligible.

The relative changes in runoff (Fig. 11d) were the most important during the winter. An increase of $162 \%$ of the runoff was simulated between December and April. The snow melt runoff peak between May and September was less affected (16\% reduction).

\section{Discussion and conclusion}

The objective of this paper was to analyze the combined effect of climate and land cover changes, which are expected to occur over the 21 st century, on the snow cover of the Bassiès catchment. For this purpose, we used a distributed snowpack evolution model (SnowModel) that includes a series of parameterizations to represent the snow-vegetation interactions.

SnowModel was already applied and validated in various landscapes (Liston et al., 2007). Although SnowModel was not included in the SnowMIP-2 experiment, its snow-vegetation parameteriza- tions are similar to those implemented in several snow models of the SnowMIP-2 study (see Introduction). In addition to these previous studies, we also performed a model validation in our study area, which showed that:

- SnowModel was able to simulate the snow depth at the Bassiès station for the 2011-2012 snow season.

- SnowModel simulated a realistic distribution of the snow over the Bassiès catchment and a pertinent evolution of these changes over time.

- SnowModel was able to simulate the link between the elevation of a grid point and type of vegetation covering a specific grid cell with the snow probability of the cell.

This validation was limited over a short time period (one snow season) and did not allow a thorough model validation or calibra- 
tion. However, our assessment and the previous validation studies suggests that SnowModel, with its default parameters, is a relevant tool for investigating climate and vegetation changes that impact the study area. However, we identified an overestimation of the snow cover duration in regions of high elevation in the catchment, which may be the result of various causes, including (i) an inaccurate model parameterization, e.g., of the air temperature and/or precipitation lapse rates; and (ii) a lack of process representation, e.g., downslope snow transport by avalanches and/or preferential deposition of falling snow because of topographically induced wind field perturbations during a storm (Lehning et al., 2008). The main limitation is most likely related to the lack of information regarding the precipitation lapse rate. It would be more realistic to use several precipitation gauges over the study area to better constrain the precipitation grid computed by the model. However, the results of the lapse rate sensitivity analysis (Fig. 5) showed that an optimisation of the precipitation lapse rate may not be sufficient to improve the model performances regarding the spatial distribution of the precipitation. Even a zero PLR does allow a sufficient reduction of the snow covered area over bare soil and low vegetation areas. This is probably due to the fact that the precipitation lapse rate formulation in SnowModel (precipitation change with elevation is proportional to the precipitation rate, Liston and Elder, 2006b) is too simplistic to describe the natural heterogeneity of the snowfall patterns in complex terrain at small scale. In particular, there might be a preferential deposition of the snow at the station location relative to the surrounding slopes. This is a typical bias in snowfall measurement, but was only recently acknowledged (Wirz et al., 2011; Grünewald and Lehning, 2013). As a result the interpolated precipitation is probably overestimated in our simulation.

Regarding the impact of land-cover change on the snow depth, the model results indicated that when the forest stretches over land, the snow deposition and accumulation during snowfalls are smaller on average over the basin and the snowmelt is slower. For this reason, the mean snow depth averaged over the basin for the whole snow season was smaller than what was currently observed; however, the snow cover duration was not impacted, and the smaller snow quantities obtained by considering the expected vegetation change disappeared more slowly, which offset the vegetation impact on the snow cover duration at the whole snow season scale (see Fig. 8 and Table 3). These results are in agreement with the SnowMIP-2 conclusions (Rutter et al., 2009; Essery et al., 2009). Indeed, the interception processes were initially greater on forested areas, and a more limited snow deposition was also observed on the soil surface under the trees. The simulated decrease in snow depth is explained by the fact that the canopy unloading mainly occurs when the intercepted snow melts. During the snowmelt phase, high vegetation tended to intercept the incoming solar radiation and decrease the quantity of energy arriving to the soil surface under the trees when compared to the amount of energy that directly arrives on low vegetation in grassland and subalpine meadows. The model suggests that the shading effect due to obstruction of incoming solar radiation by the tree branches prevails over the effect of litter deposition from the trees on the soil, resulting in a lower snowmelt rate. This is due to the fact that most forested areas are projected to be colonized by evergreen species, which have a year-round shading effect. These insights were confirmed by the more extreme scenario in which the whole catchment was reforested (except bare rocks and surface water areas). This scenario showed that the tree interception was even greater in this case and the snow ablation was even slower during the snowmelt. This last scenario is also interesting to consider because the first three land cover scenarios did not explicitly consider the impact of climate change on the reforestation process, although mountain land cover evolution is known to be sensitive to climate change (e.g. Theurillat and Guisan, 2001; Beniston, 2003a). One could argue that the climate change effect on the vegetation is indirectly already included in the land cover projections since they are based on an empirical regression between two historical datasets, which are dated within the anthropogenic climate change era (1983 and 2008). This assumes that the climatic trend affecting the area between 1983 and 2008 will remain constant in the future. In our study area, the projected increase of the air temperature by the end of the century may allow faster land cover changes than those simulated by the LCM. This would tend to extend the reforestation area in the regions of high elevation in the catchment area. Scenario 4 indicates that this process would intensify the impacts on the snow cover obtained from scenarios 1 to 3 only. However, the response of land cover to climate change is complex and this issue should be the focus of a future study.

Changing temperatures generate the greatest impact on the snow depth and affect areas located between 1500 and $2000 \mathrm{~m}$ a.s.l. more acutely. Interestingly, the land cover changes are also expected to occur in the same area between 1500 and $2000 \mathrm{~m}$ a.s.l. Thus, this transition zone appears as the most sensitive to future environmental conditions. The expected temperature change decreases the snow cover duration by $30 \%$ on average in the transition areas. In addition to a decrease of the snow fraction falling during the snow accumulation over the transition areas, increased temperatures could generate a faster snowmelt phase during the ablation and reduce the snow cover duration over the entire catchment.

The projected climate and land cover changes have a low impact on the runoff because the amount of snow is preserved in the high altitude areas where the precipitation phase is unaffected by temperature changes and land cover is stable. These high elevation areas store most of the snowpack at the catchment scale and continue to provide most of the snow melt runoff. Moreover, these changes have consequences on the areas located below $2000 \mathrm{~m}$ a.s.l. and a greater effect on the runoff during the low water period. The impact of the snow cover changes on runoff are also damped by the fact that liquid precipitation contributes to (54\%) of the runoff in this area. This is representative of the typical hydrological regime in the Pyrenees.

The results obtained for the three other hydrological variables were analyzed in more detail (not shown) and showed that air temperature and vegetation impact the static sublimation, whereas the differences observed between the current and expected canopy unloading and wind transport are the result of land cover evolution.

These results were obtained at the local scale with a limited meteorological dataset; however, the Bassiès catchment is also representative of a common temperature and vegetation scenario in the Pyrenees. Therefore, these results may help to better anticipate the impact of ongoing climatic and land cover changes on the water resources at the scale of the Pyrenees. However, similar studies should be conducted in larger gauged catchments to better characterize the response of the snow melt runoff to future environmental conditions. The transition zone where most of the impact is concentrated may represent a larger fraction of the catchment area at a larger scale. More field work is required to better validate the model simulation under forested areas, in which conflicting processes can influence the snowpack mass balance in multiple ways depending on the tree type and development.

Finally, this work considered the snow cover from a hydrological perspective, but the results may help predict the impact of changing snow cover on other environmental phenomena, such as geomorphological and biological processes, or on the socio-economic activities associated with winter tourism. 


\section{Acknowledgements}

The work of C. Szczypta was supported by the Pyrenees Climate Change Observatory (OPCC-POCTEFA EFA-235 project). We thank the OHM Haut-Vicdessos Human-Environmental Observatory and its director Didier Galop for logistic and financial support. We greatly thank G.E. Liston, who provided the MicroMet/SnowModel code. The SPOT images were acquired as part of the ISIS Project $\mathrm{n}^{\circ} 567$. We thank Eric Martin and Aaron Boone for a fruitful discussion on this study. We also warmly thank Philippe Dupui and our colleagues at CESBIO who helped us install and maintain the meteorological instruments.

\section{References}

Anderson, E.A., 1976. A point of energy and mass balance model of snow cover. NOAA Tech. Rep. NWS 19, 1-150.

Andréassian, V., 2004. Waters and forests: from historical controversy to scientific debate. J. Hydrol. 291 (1), 1-27.

Beniston, M., 2003a. Climatic change in mountain regions: a review of possible impacts. In: Climate Variability and Change in High Elevation Regions: Past, Present \& Future. Springer, Netherlands, pp. 5-31.

Beniston, M., Keller, F., Koffi, B., Goyette, S., 2003b. Estimates of snow accumulation and volume in the Swiss Alps under changing climatic conditions. Theor. Appl. Climatol. 76 (3-4), 125-140.

Chen, J.M., Rich, P.M., Gower, S.T., Norman, J.M., Plummer, S., 1997. Leaf area index of boreal forests: Theory, techniques, and measurements. J. Geophys. Res.: Atm. (1984-2012) 102 (D24), 29429-29443.

Colin, J., Déqué, M., Radu, R., Somot, S., 2010. Sensitivity study of heavy precipitation in Limited Area Model climate simulations: influence of the size of the domain and the use of the spectral nudging technique. Tellus A 62 (5), 591-604.

Deems, J.S., Fassnacht, S.R., Elder, K.J., 2008. Interannual consistency in fractal snow depth patterns at two Colorado mountain sites. J. Hydrometeorol. 9 (5), $977-$ 988.

Delgado, J., Llorens, P., Nord, G., Calder, I.R., Gallart, F., 2010. Modelling the hydrological response of a Mediterranean medium-sized headwater basin subject to land cover change: the Cardener River basin (NE Spain). J. Hydrol. 383 (1), 125-134.

Déqué, M., 2010. Regional climate simulation with a mosaic of RCMs. Meteorol. Z. 19 (3), 259-266.

Dickinson, R.E., 1983. Land surface processes and climate-surface albedos and energy balance. Adv. Geophys. 25, 305-353.

Dozier, J., 1989. Spectral signature of alpine snow cover from the Landsat Thematic Mapper. Remote Sens. Environ. 28, 9-22.

Eastman, R., 2009. Idrisi Taiga, Guide to GIS and Image Processing, manual version 16.02. Clark University, 342p.

Essery, R., Rutter, N., Pomeroy, J., Baxter, R., Stähli, M., Gustafsson, D., Barr, A., Bartlett, P., Elder, K., 2009. SNOWMIP2: An evaluation of forest snow process simulations. Bull. Am. Meteorol. Soc. 90 (8), 1120-1135.

Etchevers, P., Martin, E., Brown, R., Fierz, C., Lejeune, Y., Bazile, E., Boone, A., Dai, Y., Essery, R., Fernandez, A., Gusev, Y., Jordan, R., Koren, V., Kowalczyk, E., Nasonova, N.O., Pyles, R.D., Schlosser, A., Shmakin, A.B., Smirnova, T.G., Strasser, U., Verseghy, D., Yamazaki, T., Yang, Z., 2004. Validation of the energy budget of an alpine snowpack simulated by several snow models (SnowMIP project). Ann. Glaciol. 38 (1), 150-158.

Fettweis, X., van Ypersele, J.P., Gallée, H., Lefebre, F., Lefebvre, W., 2007. The 19792005 Greenland ice sheet melt extent from passive microwave data using an improved version of the melt retrieval XPGR algorithm. Geophys. Res. Lett. 34 (5).

Fowler, H.J., Blenkinsop, S., Tebaldi, C., 2007. Linking climate change modelling to impacts studies: recent advances in downscaling techniques for hydrological modelling. Int. J. Climatol. 27 (12), 1547-1578.

Gallart, F., Llorens, P., 2004. Observations on land cover changes and water resources in the headwaters of the Ebro catchment, Iberian Peninsula. Phys. Chem. Earth, parts A/B/C 29 (11), 769-773.

Galop, D., Jalut, G., 1994. Differential human impact and vegetation history in two adjacent Pyrenean valleys in the Ariège basin, southern France, from 3000 BP to the present. Veg. Hist. Archaeobotany 3 (4), 225-244.

Galop, D., Houet, T., Mazier, F., Leroux, G., Rius, D., 2011. Grazing activities and biodiversity history in the Pyrénées-the use of paleoecology and historical ecology to provide new insights on high-altitude ecosystems in the framework of a Human-Environment Observatory. PAGES news 19 (2), 53-55.

García-Ruiz, J.M., Lana-Renault, N., 2011. Hydrological and erosive consequences of farmland abandonment in Europe, with special reference to the Mediterranean region-a review. Agric., Ecosyst. Environ. 140 (3), 317-338.

Gascoin, S., Lhermitte, S., Kinnard, C., Borstel, K., Liston, G.E., 2013. Wind effects on snow cover in Pascua-Lama, Dry Andes of Chile. Adv. Water Resour. 55, 25-39.

Goubanova, K., Li, L., 2007. Extremes in temperature and precipitation around the Mediterranean basin in an ensemble of future climate scenario simulations. Glob. Planet. Chang. 57 (1), 27-42.
Graveline, N., Majone, B., Van Duinen, R., Ansink, E., 2014. Hydro-economic modelling of water scarcity under global change: an application to the Gallego river basin (Spain). Reg. Environ. Change 14 (1), 119-132.

Greene, E.M., Liston, G.E., Pielke, R.A., 1999. Simulation of above treeline snowdrift formation using a numerical snow-transport model. Cold Reg. Sci. Technol. 30 (1), 135-144.

Grünewald, T., Lehning, M., 2013. Do snow depth measurement at typical flat-field locations represent total snow at catchment scale ? In: DACA-13: Davos Atmosphere and Cryosphere Assembly DACA-13, Air, Ice and Process Interactions. An IUGG (IAMAS and IACS) Event, July 8-12, Davos, Switzerland. Abstract proceedings. Davos, 8.

Habets, F., Philippe, E., Martin, E., David, C.H., Leseur, F., 2013. Small farm dams: impact on river flows and sustainability in a context of climate change. Hydrol. Earth Syst. Sci. Discuss. 10 (11).

Hardy, J.P., Melloh, R., Robinson, P., Jordan, R., 2000. Incorporating effects of forest litter in a snow process model. Hydrol. Process. 14 (18), 3227-3237.

Hedstrom, N.R., Pomeroy, J.W., 1998. Measurements and modelling of snow interception in the boreal forest. Hydrol. Process. 12 (1011), 1611-1625.

Hellström, R.Å., 2000. Forest cover algorithms for estimating meteorological forcing in a numerical snow model. Hydrol. Process. 14 (18), 3239-3256.

Houet, T., Ribière, O., Vacquié, L., Vidal, F., Galop, D., 2012. Analyse spatiale de l'évolution des modes d'occupation et d'usages des sols sur le Vicdessos de 1942 à nos jours. Sud-Ouest Européen.

Houet, T., Galop, D., Vacquié, L., Vidal, F., Sheeren, D., 2014. Monitoring LUCC in the Human-Nature mountain observatory of the Haut-Vicdessos (Pyrenees, France) from the 1940s using aerial photographs. Global Fair and Workshop on LongTerm Observatories of Mountain Social-Ecological Systems, Reno (USA), 1619 th July 2014.

Jost, G., Weiler, M., Gluns, D.R., Alila, Y., 2007. The influence of forest and topography on snow accumulation and melt at the watershed-scale. J. Hydrol. 347 (1), 101-115.

Koivusalo, H., Kokkonen, T., 2002. Snow processes in a forest clearing and in a coniferous forest. J. Hydrol. 262 (1), 145-164.

Le Treut, H., 2003. Les scénarios globaux de changement climatique et leurs incertitudes. Comptes Rendus Geosci. 335 (6), 525-533.

Lehning, M., Löwe, H., Ryser, M., Raderschall, N., 2008. Inhomogeneous precipitation distribution and snow transport in steep terrain. Water Resour. Res. 44 (7).

Liston, G.E., 1995. Local advection of momentum, heat, and moisture during the melt of patchy snow covers. J. Appl. Meteorol. 34 (7), 1705-1715.

Liston, G.E., Elder, K., 2006a. A distributed snow-evolution modeling system (SnowModel). J. Hydrometeorol. 7 (6), 1259-1276.

Liston, G.E., Elder, K., 2006b. A meteorological distribution system for highresolution terrestrial modeling (MicroMet). J. Hydrometeorol. 7 (2), 217-234.

Liston, G.E., Hall, D.K., 1995. Sensitivity of lake freeze-up and break-up to climate change: a physically based modeling study. Ann. Glaciol. 21, 387-393.

Liston, G.E., Pielke, R.A., 2001. A climate version of the regional atmospheric modeling system. Theor. Appl. Climatol. 68 (3-4), 155-173.

Liston, G.E., Haehnel, R.B., Sturm, M., Hiemstra, C.A., Berezovskaya, S., Tabler, R.D., 2007. Instruments and methods simulating complex snow distributions in windy environments using SnowTran-3D. J. Glaciol. 53 (181), 241-256.

López-Moreno, J.I., García-Ruiz, J.M., 2004. Influence of snow accumulation and snowmelt on streamflow in the central Spanish Pyrenees/Influence de l'accumulation et de la fonte de la neige sur les écoulements dans les Pyrénées centrales espagnoles. Hydrol. Sci. J. 49 (5).

López-Moreno, J.I., Latron, J., 2008. Spatial heterogeneity in snow water equivalent induced by forest canopy in a mixed beechfir stand in the Pyrenees. Ann. Glaciol. 49 (1), 83-90.

López-Moreno, J.I., Beniston, M., García-Ruiz, J.M., 2008. Environmental change and water management in the Pyrenees: facts and future perspectives for Mediterranean mountains. Glob. Planet. Chang. 61 (3), 300-312.

López-Moreno, J.I., Moran-Tejeda, E., Vicente Serrano, S.M., Lorenzo-Lacruz, J. García-Ruiz, J.M., 2011. Impact of climate evolution and land use changes on water yield in the Ebro basin. Hydrol. Earth Syst. Sci. 15, 311-322.

López-Moreno, J.I., Zabalza, J., Vicente-Serrano, S.M., Revuelto, J., Gilaberte, M., Azorin-Molina, C., Morán-Tejeda, E., García-Ruiz, J.M., Tague, C., 2014. Impact of climate and land use change on water availability and reservoir management: Scenarios in the Upper Aragón River, Spanish Pyrenees. Sci. Total Environ. 493 $1222-1231$.

Lundberg, A., Nakai, Y., Thunehed, H., Halldin, S., 2004. Snow accumulation in forests from ground and remote-sensing data. Hydrol. Process. 18 (10), 1941 1955.

Majone, B., Bovolo, C.I., Bellin, A., Blenkinsop, S., Fowler, H.J., 2012. Modeling the impacts of future climate change on water resources for the Gállego river basin (Spain). Water Resour. Res. 48 (1).

Marks, D., Kimball, J., Tingey, D., Link, T., 1998. The sensitivity of snowmelt processes to climate conditions and forest cover during rain-on-snow: a case study of the 1996 Pacific Northwest flood. Hydrol. Process. 12, 1569-1587.

Mas, J.F., Kolb, M., Paegelow, M., Olmedo, M.T.C., Houet, T., 2014. Modelling Land use/cover changes: a comparison of conceptual approaches and softwares. Environ. Model. Softw. 51, 94-111.

Mellander, P.E., Laudon, H., Bishop, K., 2005. Modelling variability of snow depths and soil temperatures in Scots pine stands. Agric. For. Meteorol. 133 (1), 109118.

Morán-Tejeda, E., Ceballos-Barbancho, A., Llorente-Pinto, J.M., 2010. Hydrological response of Mediterranean headwaters to climate oscillations and land-cover 
changes: the mountains of Duero River basin (Central Spain). Glob. Planet. Chang. 72 (1), 39-49.

Niu, G.Y., Yang, Z.L., 2004. Effects of vegetation canopy processes on snow surface energy and mass balances. J. Geophys. Res.: Atmos. (1984-2012), 109, D23.

Pachauri, R.K., 2008. Climate change 2007. Synthesis report. Contribution of Working Groups I, II and III to the fourth assessment report.

Pomeroy, J.W., Gray, D.M., Hedstrom, N.R., Janowicz, J.R., 2002. Prediction of seasonal snow accumulation in cold climate forests. Hydrol. Process. 16 (18), 3543-3558.

Poyatos, R., Latron, J., Llorens, P., 2003. Land use and land cover change after agricultural abandonment: the case of a Mediterranean mountain area (Catalan pre-Pyrenees). Mt. Res. Dev. 23 (4), 362-368.

Quintana-Seguí, P., Le Moigne, P., Durand, Y., Martin, E., Habets, F., Baillon, M., Canellas, C., Franchisteguy, L., Morel, S., 2008. Analysis of near-surface atmospheric variables: validation of the SAFRAN analysis over France. J. Appl. Meteorol. Climatol. 47 (1), 92-107.

Radu, R., Déqué, M., Somot, S., 2008. Spectral nudging in a spectral regional climate model. Tellus A 60 (5), 898-910.

Roesch, A., Wild, M. Gilgen, H., Ohmura, A., 2001. A new snow cover fraction parametrization for the ECHAM4 GCM. Clim. Dyn. 17 (12), 933-946.

Ross, J., 1981. The Radiation Regime and Architecture of Plant Stands. W. Junk, 391 p.

Rousselot, M., Durand, Y., Giraud, G., Mérindol, L., Dombrowski-Etchevers, I., Déqué, M., 2012. Statistical adaptation of ALADIN RCM outputs over the French alpine massifs-application to future climate and snow cover. Cryosphere Discuss. 6 (1), 171-210.

Rutter, N., Essery, R., Pomeroy, J., Altimir, N., Andreadis, K., Baker, I., Barr, A., et al., 2009. Evaluation of forest snow processes models (SnowMIP2). J. Geophys. Res.: Atm. (1984-2012), 114, D6.

Sellers, W.D., 1985. The effect of a solar perturbation on a global climate model. J. Clim. Appl. Meteorol. 24 (8), 770-776.

Sproles, E., Nolin, A., Rittger, K., Painter, T., 2012. Climate change impacts on maritime mountain snowpack in the Oregon Cascades. Hydrol. Earth Syst. Sci. Discuss. 9 (11), 13037-13081.

Talbot, J., Plamondon, A.P., Levesque, D., Aube, D., Prevos, M., Chazalmartin, F., Gnocchini, M., 2006. Relating snow dynamics and balsam fir stand characteristics, Montmorency Forest, Quebec. Hydrol. Process. 20 (5), 11871199.

Theurillat, J.P., Guisan, A., 2001. Potential impact of climate change on vegetation in the European Alps: a review. Clim. Chang. 50 (1-2), 77-109.

Varhola, A., Coops, N.C., Weiler, M., Moore, R.D., 2010. Forest canopy effects on snow accumulation and ablation: an integrative review of empirical results. J. Hydrol. 392 (3), 219-233.

Vicente-Serrano, S.M., Lasanta, T., Romo, A., 2004. Analysis of spatial and temporal evolution of vegetation cover in the Spanish Central Pyrenees: role of human management. Environ. Manag. 34 (6), 802-818.

Wirz, V., Schirmer, M., Gruber, S., Lehning, M., 2011. Spatio-temporal measurements and analysis of snow depth in a rock face. The Cryosphere 5, 893-905. http:// dx.doi.org/10.5194/tc-5-893-2011. 